\title{
A Review of the genera Meconopsis and Cathcartia.
}

\author{
BY
}

\author{
D. PRAIN, C.I.E., F.R.S. \\ Director of the Royal Botanic Gardens, Kew.
}

With Plates XXIV and XXV.

I. MECONOPSIS.

History.

THE name Meconopsis was proposed by Viguier in I8I4 (Hist. Pav. 1 Diss., 20) for the plant known familiarly in this country as the Welsh Poppy. By the earlier systematists this plant was sometimes treated as a Papaver, sometimes as an Argemone. When included in Argemone it will be understood that the genus intended was not the Argemone of modern botanical works, first clearly defined by Tournefort in I694, but the pre-Tournefortian Argemone, all the species of which Tournefort relegated to Papaver ${ }^{1}$. The limitation of Papaver and Argemone which Tournefort advocated was substantially adopted by Linnaeus, who, in I753 (Species Plantarum, ed. I), named the Welsh Poppy Papaver cambricum.

Viguier's proposal, and his name Meconopsis cambrica, were adopted in I 8 I 5 by De Candolle (Flor. Fr., ed. 3, v. 586), but in spite of this sponsorship a generation elapsed before either the name or the view found acceptance. In I 8 I 6 Desportes (Dict. Sci. Nat., ii. $48 \mathrm{I}$ ), while assenting to the removal of the Welsh Poppy from Papaver, did not admit the necessity for a genus Meconopsis, but referred the plant to Argemone, as A. cambrica. In this case, however, it was in the new or Tournefortian Argemone, not in Argemone as understood by the early writers, that Desportes placed the Welsh Poppy. The arrangement is not a happy one, for it obscures Tournefort's Argemone without making Viguier's Meconopsis intelligible. When in I82I De Candolle dealt again with the plant (Syst. Veg., ii. 87) he gave no support to Desportes' view. However, while disposing of one difficulty De Candolle created another, because he linked with Viguier's

1 For a detailed history of the change of incidence of the name Argemone, see Journal of Botany, xxxiii, pp. I30-2.

[Annals of Botany, Vol. XX. No. LXXX. October, 19o6.] 
genus two forms of an American Celandine on which in 18 1 8 Nuttall had based his genus Stylophorum ${ }^{1}$. This treatment, which obscures the limits of Meconopsis as Desportes' had obscured those of Argemone, was repeated by De Candolle in I 824 (Prodr., i. I 2I). In the following year D. Don (Prodr. Fl. Nepal., I96) returned to the view of Tournefort and of Linnaeus and treated certain species of Meconopsis as Papavers. However, in 1827 , Sprengel (Syst., ii. 570) accepted De Candolle's view as to the relationship of Meconopsis, Vig., and Stylophorum, Nutt., but in doing so added a bibliographical difficulty to the taxonomic one, because he decided to reduce Viguier's earlier name and to employ Nuttall's later one for the composite genus. This bouleversement was accepted by G. Don in I83I (Gen. Syst., i.), and although Bernhardi in I 833 (Linnaea, viii. 462) restored Meconopsis to its proper position, the confusion was perpetuated by Steudel (Nomencl., ed. 2, ii.) in I84I, nor was it till A. Gray showed in 1848 (Gen., i. I I 4 ) that Nuttall's Stylophorum is not congeneric with Viguier's Meconopsis that the latter name came into general use.

The first genuine Meconopsis to be added to Viguier's genus was $M$. napaulensis, described by De Candolle (Prodr., i. I $2 \mathrm{I}$ ) in 1824 ; it has, however, to be noted that De Candolle treated it as a doubtful species, and that he placed it in his section Stylophorum, which should never have been included in the genus, not in Meconopsis proper. In $1825 \mathrm{D}$. Don described two others, also from Nepal (Prodr. Fl. Nepal., I96). One of them Don supposed to be identical with $M$. napaulensis; both he treated as species of Papaver. All three Nepalese species had been collected by Wallich, who issued them, with two others, from the Himalayan region but not from Nepal, in 1830 (Lith. Cat., nn. 8I II-25) as unnamed species of Meconopsis. The identity of the Wallichian Meconopses will be given in dealing with the group Robustae.

A few years later Bentham, in 1835 , described two additional forms from California. These two, $M$. heterophylla and $M$. crassifolia, have given a good deal of trouble to Californian botanists. It appears to be generally admitted that there are really two distinguishable stylate 'Poppies' in California, but it seems to be doubtful whether they represent two forms of one species differing in facies in consequence of their environment (Flor. Francisc., 281), two distinct varieties of the same species (Flor. West Mid. Calif., 209), or two different species (Bot. San Francisc. Bay, 9).

A fourth Himalayan species, which is included in the list of those issued without specific names by Wallich, was described as $M$. aculeata by Royle (Ill. Him. Pl., 67) in 1839. It was not till 1852 that another Himalayan species, the fifth from the Himalaya and the eighth species in the genus, was described by Sir W. Hooker (Bot. Mag., t. 4668). This last

1 This complication, from the point of view of Stylophorum, is disentangled in Bulletin de l'herbier Boissier, iii, p. 573 . 
species came from the Sikkim Himalaya, and although Sir W. Hooker identified with it one of Wallich's Nepalese Meconopses, it happens that this particular species, which Hooker termed $M$. Wallichii, has not yet been reported from Nepal and never was collected or seen by Wallich. The next addition to the genus was made in 1855 (Fl. Ind., 25I-4) by Hooker and Thomson, who then dealt with and accounted for all but one of the unnamed Meconopses issued by Wallich in 1830 , and described two new species, making seven for the Himalaya and ten for the whole genus. Of these new species, one ( $M$. robusta) was already, though without a name, in Wallich's collection, the other ( $M$. horridula) was not. No further additions were made to the genus till I876, when Regel (Gartenfl., xxv. 29I) described $M$. quintuplinervia, the first species to be reported from China. In the same year Maximowicz described two others from China and North-East Tibet (Mel. Biol., ix.), though one of these appears to be no more than a form of the Himalayan $M$. horridula; the other ( $M$. integrifolia) Maximowicz treated in the first instance as a Cathcartia. To these Chinese species Franchet in I 886 added two (M. Delavayi and $M$. lancifolia), which he treated as species of Cathcartia; Maximowicz in I 889 added a fifth (M. punicea), and Franchet in I89I added two more (M. Henrici and $M$. chelidonifolia). In 1894 the writer described the Himalayan $M$. bella, thus bringing the total for the Himalaya to eight, and for the whole genus to eighteen. In the following year the writer dealt with four additional Himalayan species ( $M$. primulina, $M$. simuata, $M$. superba, and $M$. grandis) and with another Chinese species (M. Oliveriana), bringing the Himalayan species up to twelve, the Chinese to eight, and the total for the genus to twenty-three. Another Himalayan species and three more Tibetan or Chinese species have now to be reported, raising the total number of distinguishable forms to twenty-seven.

\section{MORPHOLOGY.}

The Himalayan species of the genus have already received some attention on the writer's part ${ }^{1}$, and in dealing with these incidental reference has been made to some of the Chinese ones. The necessity that has arisen for the preparation of descriptions of the four additional species just mentioned calls for further discussion of the genus as a whole, and the present opportunity is taken of enumerating and reviewing all the species.

A typical Meconopsis such as the Welsh Poppy, M. cambrica, Vig., on which the genus was founded, or the blue Sikkim Poppy, $M$. Wallichii, Hook. (P1. XXIV, Fig. 6), is easily distinguished from a true Papaver, like $P$. somniferum, Linn., or $P$. dubium, Linn. (Pl. XXIV, Figs. I, 2). In both genera, as is shown in Pl. XXIV, drawn by Miss M. Smith, the ripe

1 Journ. As. Soc. Beng., lxiii. 2, 8I-2 (I 894), and lxiv. 2, 309-2I (1895); Ann. Roy. Bot. Gard. Calcutta, ix. I, 2-5, tt. 2-6 (I90I); Gard. Chron., ser. III, xxxvii. 369-70 (I905). 
capsule dehisces under the apex by means of short more or less transverse valvular chinks between the placental ribs. In the species of Papaver referred to, the vertex of the capsule is a definite disk bearing on its upper surface the radiating stigmas and more or less concealing by its projecting margin the chinks through which the seeds escape. In the species of Meconopsis cited the capsule has no disk, the chinks by which it dehisces are unconcealed, and the apex ends in a persistent style, crowned by the clavate or subcapitate slightly lobed stigma.

The two genera are, however, closely allied, and from the time of Tournefort (1694) till that of Viguier (1814) they were united. The differences between the two are not always so clearly defined as in the examples quoted; there are species of Papaver, like $P$. polychaetum, Schott and Kotschy (Pl. XXIV, Figs. 3, 4), one of the species of Papaver which constitute the section Miltantha, and correspond more or less to the preTournefortian genus Argemone, where the chinks of dehiscence are not hidden by a projecting disk-margin ; there are other species, like $P$. stylatum, Boiss. and Bal. (Pl. XXIV, Fig. 5), in the Old World, and like P. Lemmoni, Greene, in the New, where the disk projects into a distinct central style. On the other hand, a whole group of species of Meconopsis, the Grandes, has the stigma as definitely radiating as in any Papaver; in two species of this group, $M$. punicea, Maxim., and $M$. integrifolia, Franch. (Pl. XXIV, Figs. 7,8$)$, the stigma is not even separated from the body of the capsule by an intervening style; here, however, there certainly is no disk.

Again, in the Californian group of Meconopsis, the Anomalae, we find that at the base of the distinct style the vertex of the capsule is flattened and disk-like (Pl. XXIV,-Figs. 9, I0). Here, however, there is not a disk such as we have in Papaver dubium with a margin projecting beyond the transverse chinks through which the seeds are discharged; we have merely a flattening of that portion of the capsule, in this case somewhat extensive, which is interposed between the apices of the valves and the base of the style. The same feature, though not to so exaggerated an extent, and with the portion between apices of valves and style-base convex instead of flat, is met with in M. bella, Prain. In one Meconopsis, however, M. primulina, Prain, we find that on alternate, but not on all the placental ribs there are, at the base of the style, epaulette-like outgrowths which suggest the rudiments of a projecting disk-margin. It has now to be recorded that in two species of Meconopsis, M. torquata, Prain (Pl. XXIV, Fig. II), and $M$. discigera, Prain (Pl. XXIV, Fig. I2), described for the first time in the systematic portion of this paper, the capsule is surmounted by a true disk, the margin of which projects, as in a typical Papaver, beyond the series of chinks by which the seeds find egress.

We have seen that in I 825 D. Don (Prodr. Fl. Nepal., I96) did not consider the absence of a disk and the presence of a style sufficient justifica- 
tion for the recognition of Meconopsis as generically distinct from Papaver. In 1888 Greene (Pittonia, i. I68) had occasion to discuss the nature of the gynoecium in three Californian species: Papaver californicum, Gray, which has a disk like that of $P$. dubium; $P$. Lemmoni, Greene, where the vertex of the capsule, from his description, is like that of $P$. stylatum; and the plant taken by Greene to be Meconopsis heterophylla. Owing to the somewhat intermediate nature of the gynoecium of Papaver Lemmoni, Greene has decided, as Don had decided more than sixty years before, that the recognition of the genus Meconopsis, as distinct from Papaver, is uncalled for. In this view he has been followed by Jepson (Flor. West Mid. Calif., 209). From what has been said above, and from an examination of the figures in Pl. XXIV, it will be seen that the position of Don and Greene and Jepson is perhaps stronger than any of them had reason to believe.

In spite, however, of the weight of authority on the other side, the writer feels that it would be inconvenient, even if it were necessary, to adopt the suggestion made by Don and revived by Greene. Had it been merely a matter of dealing with the original European Meconopsis and the Californian forms, the conclusion might have been accepted and the species in question treated as aberrant Papavers. But we have to deal with four-and-twenty Asiatic forms as well, and in considering these we have to face another troublesome question. The genus Cathcartic, as we now know, differs from Meconopsis by only one valid character: in Meconopsis the capsules open by apical chinks, in Cathcartia the valves split to the base. If Meconopsis is an unsatisfactory genus, Cathcartia too must go. So alike are the two, that authorities so great as Maximowicz and Franchet have taken Meconopses to be Cathcartiae, and the writer believes that one species described by Franchet as a Meconopsis is really a Cathcartia. But if Cathcartia disappears nothing can save Stylophorum, and Stylophorum is, after all, only Chelidonium. Nor can we stop here. There are species of Papaver, like $P$. orientale, Linn., with 3-merous flowers; species like $P$. pavoninum, Schrenk, with horned sepals; species like $P$. horridum, DC., and like Meconopsis horridula, Hook. f. and Thoms., with spinescent leaves and capsules. We therefore find, in the conjoined genera Papaver and Meconopsis, practically every character that marks Tournefort's genus Argemone. If we follow Don and Greene in the suggestion that Viguier's work be cancelled, we may find ourselves left without a landmark in the natural family Papaveraceae.

The occurrence of intermediate forms is not in itself a sufficient reason in all cases for the combination of nearly allied genera. To cite familiar instances where there really are intermediates, no one seriously thinks of uniting Aconitum and Delphinium, and few have been so bold as to advocate the reduction of Cirrhopetalum to Bulbophyllum. However, in the case now under consideration, the fusion which has been suggested is not 
urgently called for on morphological grounds. In spite of the many directions in which the one genus approaches the other, the differences between them never absolutely disappear, and it is still not only possible but easy to distinguish any species of Meconopsis hitherto reported from every species of Papaver as yet described. All that seems necessary is some modification in the popular conception of both genera, and some amendment in the usual definition of Meconopsis.

It is not as regards the gynoecium alone that modification of idea and definition is required. In Papaver, while one or two species have 3 sepals and 6 petals, the majority have 2 sepals and 4 petals in two pairs, an arrangement so characteristic of the natural family Papaveraceae as to have received the name 'papaveroid.' With few exceptions ${ }^{1}$ the definitions of Meconopsis credit the genus with this arrangement and number of parts. But although it be true that every Meconopsis so far known has only 2 sepals, one-third of the species have more than 4 petals; when this is so, the petals are disposed as they are in the genus Sanguinaria. This arrangement is met with in $M$. horridula (group Aculeatae); in $M$. primulina, $M$. Henrici, and $M$. Delavayi (group Primulinae); in $M$. integrifolia, $M$. simplicifolia, $M$. grandis, and sometimes in $M$. punicea (group Grandes). Even in those groups in which the arrangement occurs, it is not in any case characteristic of the whole group ; it does, however, appear usually to be almost, if not quite, characteristic of individual species. In the systematic portion of this paper two more species, in which the corolla is 'sanguinarioid' and not 'papaveroid,' have to be dealt with.

During I899-I90I a journey was made in Tibet by Capt. P. K. Koslov. Circumstances led to his wintering just below the level of the Tibetan plateau in the valley of the Ra-chu, one of the head-waters of the Mekong ${ }^{2}$. In this locality, situated approximately in lon. $97^{\circ} 30^{\prime} \mathrm{E}$. and lat. $29^{\circ} 30^{\prime} \mathrm{N}$., some of the members of Koslov's party made a collection of seeds for the Imperial Botanic Garden, St. Petersburg. A number of the seeds thus obtained were sent by Dr. Fischer de Waldheim to Mr. A. K. Bulley, Neston. Among the plants raised by Mr. Bulley was a Meconopsis (group Grandes) with sanguinarioid yellow flowers. This plant was figured by Mr. Bulley (Flora and Sylva, iii. 80) in 1905 as M. integrifolia, a species which it indeed resembles and to which it is nearly related, but from which it differs much as $M$. simplicifolia differs from $M$. grandis. Another example of this species, presented by Mr. Bulley to Kew, flowered in the Alpine Garden there in May, I906. Having thus had an opportunity of studying it and $M$. integrifolia side by side in the living state, the writer has been able to confirm the opinion already expressed by Bulley (Flora

\footnotetext{
${ }^{1}$ Hooker and Thomson in their Flora Indica, published in 1855 , were the first to give a correct definition.

${ }^{2}$ Journ. Roy. Geogr. Soc., xix. 589 (1902).
} 
and Sylva, iii. I91) and by Hemsley (Bot. Mag., t. 8027) that this species is distinct from $M$. integrifolia. In the correspondence which has taken place regarding this plant, Dr. Fischer de Waldheim has invited the writer to name and describe the species. It is dealt with below as $M$. pseudointegrifolia (Pl. XXV).

In 1905 Messrs. James Veitch and Sons kindly allowed the writer to examine the fine collection of Meconopsis made for them in south-western China by Mr. E. H. Wilson. This collection contained ample material of $M$. chelidonifolia, Bur. and Franch., and of $M$. Oliveriana, Franch. and Prain, two species that as regards their fruits are very distinct, but that in all other respects are puzzlingly alike. It is now certain that the flowers of $M$. Oliveriana are yellow, as they are in $M$. chelidonifolia, not purplish, as the writer in 1895 was inclined to believe. Another interesting fact brought out by this collection is that $M$. Wallichii, the blue Sikkim Poppy, extends to, or at all events reappears in, Szechuen. The collection also contains fuller material of $M$. Henrici, Bur. and Franch., a species described in I89r, which has this year (1 906) flowered with Messrs. Veitch at Coombe Wood. A question has arisen with regard to this species which cannot for the moment be definitely settled, but which illustrates the difficulties that are encountered in dealing with species of this genus. In 1876 Maximowicz described for the first time the form known in gardens as $M$. racemosa. The writer has already (Journ. As. Soc. Beng., lxiv. 2, 3I 4) shown that we have reason to believe that $M$. racemosa is only a form of $M$. horridula with agglutinated instead of discrete scapes. An opportunity since I895 of examining both forms as they grow, side by side, in southern Tibet has tended to confirm the writer in this opinion. Though it probably will be convenient in horticulture to continue the use of the name $M$. racemosa, there is hardly room for doubt that $M$. racemosa and $M$. horridula are conspecific. In 1886 Franchet described as a Cathcartia the Meconopsis lancifolia (group Primulinae) of this paper, a species which, like $M$. racemosa among the Aculeatae, has flowers in raceme-like cymes without bracts subtending the individual flowers. Now that fruiting specimens of $M$. Henrici are available it is found that its capsules are quite like those of M.lancifolia, and there is room for suspicion that $M$. lancifolia from Yunnan may bear to $M$. Henrici from Szechuen somewhat of the relationship that $M$. racemosa bears to $M$. horridula.

The receipt of further material of the plant, which in 1895 the writer dealt with as $M$. simuata, var. Prattii, shows that it is not referable to $M$. simuata. In $M$. simuata there are 4 petals and the capsule is very like that of $M$. Henrici, whereas the form in question has $5^{-8}$ petals, and has a fruit more like that of $M$. aculeata and $M$. horridula, but smaller than in either of these species. It now appears that $M$. simuata, var. Prattii, from Szechuen is identical with a plant from Yunnan which the writer treated as 
a variety (var. nudis) of $M$. horridula. This plant, as was pointed out eleven years ago, is the $M$. racemosa of Franchet (Pl. Delavay., 4I) but not the $M$. racemosa of Maximowicz. Now that more complete material is available it seems advisable to treat this Yunnan and Szechuen plant as a distinct species of the group Aculeatae. The writer has already pointed out that $M$. horridula, with its variety racemosa, is virtually a Tibetan species which only casually overflows through some of the eastern Himalayan passes into the higher valleys of Sikkim and Chumbi. In the north-western Himalaya, from Kamaon to Kashmir, we find $M$. horridula replaced by a representative species, $M$. aculeata; in the eastern Himalaya $M$. horridula is, at slightly lower elevations, replaced by another representative species, $M$. simuata. It now appears that in the corresponding area and at corresponding elevations in Szechuen and Yunnan $M$. horridula is similarly replaced by this third representative species, which is described below as $M$. rudis.

\section{TAXONOMY.}

In arranging the species of Meconopsis the most satisfactory method is found to be that of grouping those species which agree in the greatest number of characters. This is not difficult, because, while we find in this as in other high alpine genera that the distribution of individual species is usually limited, we also find a complementary tendency to the occurrence, in distinct areas where the general conditions are similar, of representative species. The groups that it is necessary to recognize are somewhat unequal in number of component forms; these groups, rather than the actual species, probably represent the natural units of the genus. For further aggregation it is necessary to look for characters common to the various groups. Within the limits of the genus there is a wealth of striking differential morphological features and physiological peculiarities. Thus some species have stems, now simple now branched; others have none. Some have, others want a style; some have, others are without a disk. Some have papaveroid, others have sanguinarioid corollas; some have radiating divaricate, others have decurrent contiguous stigmatic lobes. Then some species are monocarpic, others are polycarpic; some have crowns that persist, others have crowns that die down during winter. Some flower in the same season as the seed, others flower in one year, or in two years, or occasionally after more than two years from seed. The temptation to employ as primary one or other of these salient differential characters is considerable. But further examination of all of them in the light of the actual characters of the natural groups shows us that the subdivision they effect is never complete. They traverse the evidence afforded by the actual groups and show us that in taxonomy there is no place for either morphological or physiological prepossessions. There is, however, one character, 
at first sight trivial as compared with any of those enumerated, which can be used without violating the limits of any of the groups. This is derived from the nature of the hairs which compose the indumentum; these are sometimes simple, at others barbellate.

By the use of this character we are able to aggregate five of the natural groups into a section, Eumeconopsis, all the species of which have simple hairs; and into a second section, Polychactia, the four remaining groups, all the species of which have barbellate hairs.

The five groups included in the section Eumeconopsis arrange themselves in two sub-sections, with the stems in one case slender and branching, in the other stouter, scapose and unbranched or altogether suppressed. The groups with slender stems that are or may be branched are the Cambricae, including only $M$. cambrica, perennial in duration, with no disk, a native of Europe; and the Anomalae, which are annuals, have the vertex of the capsule flattened and disk-like, and are natives of California. In these groups the indumentum is so sparingly present that the species are usually described as glabrous; we, however, always find hairs on the sepals of $M$. cambrica, and in the Anomalae we always find hairs on the margins of the leaves where they taper into or run along the sides of the petioles. The groups with unbranched stems or simple radical or pseudo-radical scapes are further easily sub-divided into the Aculeatae, which are prickly and may have either pinnately lobed or simple leaves; and into two unarmed groups, the Primulinae, monocarpic, with simple leaves, flowering one year from seed, and the Bellae with dissected leaves, a perennial habit, and only flowering after two or more years from seed. The four groups included in the section Polychactia likewise arrange themselves in two sub-sections; one with the stems simple and scapose or altogether suppressed, the other with the stems branched. The groups with simple stems or no stems are two in number; the Grandes without a disk and with the stigmatic lobes radiating and divaricate, and the Torquatae with a true and well-developed disk and with the stigmatic lobes decurrent and contiguous. The two groups with branching stems are the Robustae, a very distinct group with stout muchbranched stems with numerous flowers, monocarpic, with persistent crowns, flowering in the second year from seed; and the Chelidonifoliae with slender stems, few flowers, and a perennial habit. This last group consists of two species so remarkably alike that they can only be distinguished by their fruits; one of them has a stigma like that met with in the group Grandes, the other a stigma like that met with in all the groups except the Grandes. The Chelidonifoliae resemble, in general appearance, the group Cambricae, with which the writer at one time associated them. The affinity of the two groups outside the genus is, however, rather different; M. cambrica but for its capsule is a Stylophorum, the Chelidonifoliae but for their capsules are Cathcartiae. 
The species of Meconopsis, with the exception of the forms from California which are annuals, have generally been described as perennials. It is not impossible that under natural oecological conditions a fair proportion of them may be so ; in cultivation, however, few of them are. Though none except the Californian forms are truly annual, most of them are monocarpic. In order to supplement his own knowledge and experiencé, the writer has consulted various friends who have had species of Meconopsis in cultivation, and is indebted for much of the information given below to Professor Bayley Balfour of Edinburgh, Mr. M. L. de Vilrmoin of Paris, Messrs. J. Veitch \& Sons of Coombe Wood, and Mr. W. Irving of the Herbaceous Department at Kew. The evidence from herbarium material is rarely conclusive as regards species that have not yet been introduced to horticulture, and the only two as to which dried specimens appear to afford definite proof of a perennial habit are $M$. chelidonifolia and $M$. Oliveriana. In discussing the species seriatim it will be most convenient if they are dealt with group by group.

Cambricae. A single species, M. cambrica. Grows freely in most English gardens; is always perennial; as a rule self-sown seedlings appear in quantity.

Anomalae. Two forms, possibly not distinct species, $M$. crassifolia and $M$. heterophylla. Always hardy annuals, ripening seed readily in England.

Aculeatae. Two species of this group, M. simuata and $M$. rudis are not yet known in cultivation; this is also true of $M$. horridula. Of the remaining forms $M$. aculeata is very familiar. At Kew, plants of this species flower in about a year from time of germination, occasionally they take two years. They lose their crown of leaves during the winter months. Usually this species lasts only one year, dying after flowering; at Kew, however, there has been one instance of a plant flowering two years in succession. At Edinburgh, though usually monocarpic, it is not always so, and Professor Balfour reports that several plants of this species have gone through three years of flowering. Self-sown seedlings frequently appear in the vicinity of the spot where a plant of $M$. aculeata has flowered. The other form of this group known in gardens is $M$. racemosa, Maxim. This is a biennial, flowering in a year from seed. It grows well and ripens seed freely. It is somewhat significant that this, which the writer takes to be only a condition, or at most a variety of $M$. horridula, should be well known, while true $M$. horridula is not known in cultivation. In the higher valleys of Sikkim, which the species, whereof both $M$. horridula and $M$. racemosa appear to be states, invades by crossing the inner passes, this is plentiful; it does not, however, appear to occur below 14,000 feet or to the south of the outer passes and of the line of snowy peaks like Kinchinjanga, Chumiamo and Kinchinjhao, that mark the main axis of the Himalaya in this region. Below I 4,000 feet and to the south of these peaks the species is sparingly replaced by $M$. sinuata, apparently a distinct though nearly related species which is represented at corresponding altitudes in the western Himalaya by $M$. aculeata, and in alpine Yunnan and Szechuen by $M$. rudis. To the north of these snowy peaks, and on the inner passes such as the Kongra-lama and the Tang-la, the form usually 
met with is $M$. horridula; at or above $\mathrm{I} 6,000$ feet this is practically the only form present. To the north of the inner passes below 16,000 feet both forms occur side by side, and there is every transition between $M$. horridula proper with all the scapes simple, discrete, and radical; $M$. horridula still, but with some or all of the scapes agglutinated at the base; and $M$. racemosa, with all the flower disposed on a central several-flowered scape in a bractless raceme-like cyme. In specimens from the hills above Lhassa we sometimes find that the lowest and lastopening flower of this cyme is subtended by a leafy bract such as is associated with the lowest three-fourths to four-fifths of the flowers of $M$. aculeata and $M$. simuata, and with the lowest half to two-thirds of the flowers of $M$. rudis. When we take into consideration the fact that the form distinguished by Maximowicz as $M$. racemosa occurs throughout central and eastern as well as southern Tibet, and is the only form that overflows into the high alpine valleys of Szechuen and Kansuh, while $M$. horridula is confined to southern Tibet and the high alpine valleys of Sikkim and Phari, it is reasonable to surmise that $M$. horridula may be no more than a somewhat reduced condition of a Tibetan species whereof $M$. racemosa is the usual state.

The evidence from the Aculeatae, incomplete though it be, is sufficient to show that the morphological character based on the presence or absence of a stem, though it has in the past been considered of sectional value, is not adequate to distinguish one form from another as species. It is also sufficient to show that the physiological features of a monocarpic or polycarpic habit, or of flowering in one year or two years from seed, do not always hold good in individual species.

Primulinae. Three species of this group, $M$. Delavayi, $M$. lancifolia and M. primulina are unknown in cultivation. The remaining species, M. Henrici, has recently been introduced to English gardens. Its behaviour at Coombe Wood in the hands of Messrs. Veitch and Sons, who have had much experience in growing species of Meconopsis, leads them to think that it cannot be perennial. It flowers in one year from seęd.

Bellae. This group includes a single species, M. bella. Seeds of this sent to Europe by the writer from India have germinated at Kew, with Lieut.-Col. D. D. Cunningham at Torquay, with Mr. Bulley at Neston. They have also germinated at Geneva and elsewhere on the continent. It was stated in $\mathbf{r}_{9 \circ 5}$ (Flora and Sylva, iii. I66, and Gard. Chron., ser. III. xxxvii. 370), that plants at Baden and at Edinburgh were likely to flower. Actual flowering was not, however, announced for either place, and the first record of its blossoming in cultivation has come this year (I906) from Edinburgh. $\operatorname{In}_{\mathrm{t}}$ the case of this species two years have elapsed between seed and flower; there is little doubt that it is truly polycarpic. The crown of leaves persists during the winter. Unlike all other species so far known, this grows naturally on the faces of vertical cliffs; instead of flowering in spring or early summer, it flowers in late summer and autumn.

Grandes. This, the largest and one of the most natural of the groups of species in the genus, is characterized by the existence of a stigma like that of Cathcartia, section Eucathcartia. Striking, however, as this peculiarity is, it is not confined to the group; it recurs in the otherwise very different group Chelidonifoliae, a single member 
of which has a stigma of the same character. This group also traverses the character to be derived from the stem, for two species, $M$. integrifolia and $M$. grandis, have distinct stems; the others have none. It traverses besides the character based on the presence or absence of a style; two species, $M$. integrifolia and $M$. punicea, have none; the others have a well-developed style. The group treats outstanding physiological features with equally scant ceremony. $M$. punicea, $M$. quintuplinervia, $M$. simplicifolia, and $M$. pseudointegrifolia all flower in one year from seed, all lose their crown of leaves during the intervening winter, and all die after flowering. $M$. integrifolia, too, has proved monocarpic with all those, and they are now numerous, who have grown it in Europe. At Kew this species flowers in twelve months from seed, loses its crown of leaves during the winter months, and dies after flowering. Both at Kew and at Coombe Wood it is found that plants a year old which fail to flower, die at the same time as plants of the same batch which have flowered. Seeds are found to ripen freely and germinate quickly if sown when ripe. They also germinate well if kept till the following spring. Messrs. Veitch \& Sons find the best results are obtained by sowing in June and planting out when the seedlings are $2-2.5$ in. high ; plants so treated flower early in the summer following. A curious deviation from the experience at Kew and Coombe Wood has, however, been recently recorded by Mr. G. M. Sanders (Garden, lxx. Ioo), where seed of this species did not germinate till a year after sowing, and Mr. M. L. de Vilmorin has also experienced an equally interesting deviation with plants of $M$. integrifolia which, owing to a casual exigency, had to be grown in pots instead of being planted out. These did not flower in one year from seed and yet did not die. They lived through a second winter and flowered, as the species of the group Robustae do, in the second year from seed, dying after flowering. For this species it is found at Coombe Wood that full exposure is essential and that the plants improve if there are cold rough nights during the flowering stage. This experience, to those familiar with the climatic conditions of the Tibetan borderland, is not surprising. The plants flower well in open quarters but the best results are obtained in partial shade. M. grandis, the last species of this group, was introduced to European horticulture from India a number of years ago. The first to flower the plant in England was the late Mr. Thompson of Ipswich. It has since been flowered at Coombe Wood, at Neston, and at Edinburgh. At Kew this, like $M$. bella, has always perished in the seedling stage. At Coombe Wood it flowered poorly and did not prove perennial. At Neston it has proved polycarpic but has only been kept alive under protection. At Edinburgh, however, it has done well and has proved definitely polycarpic. Writing in August, I906, Professor Balfour says: 'About a dozen plants which flowered this year are now forming their new crown-bud foliage. One old plant has flowered in at least a dozen successive years and is vigorous, with a group of daughter lateral shoots at the base.' At Edinburgh the crown leaves persist during winter. If only morphological characters be considered, it is difficult to separate this species from $M$. simplicifolia, from which it mainly differs by having a distinct scapose stem and by being rather larger in all its parts. Yet $M$. simplici. folia, like the other species of the group except $M$. grandis, is monocarpic and loses its crown of leaves during the winter that intervenes between seed and flower. 
Torquatae. Of the two species in this group $M$. torquata is not yet known in cultivation; $M$. discigera has been introduced and there are young plants both at Kew and Edinburgh, probably also elsewhere. It promises, like $M$. bella, to be a species that may take several years between seed and flower; whether it is monocarpic or polycarpic cannot be predicted.

Robustae. The five species of this group appear all to behave alike. They take two years to reach the flowering stage; after flowering they die. In all, the rosette of crown-leaves persists during winter. In this group, therefore, the physiological features and morphological characters are clearly defined and distinctive to a greater degree than they are in most of the groups. At Kew the different species of the group do not behave uniformly; thus $M$. napaulensis and M. Wallichii seed freely, while $M$. paniculata seldom sets seeds. This seems to be the case with $M$. robusta also in most English gardens, and probably is so with $M$. superba. $M$. napaulensis and $M$. Wallichii come true to seed if grown separately; if grown together they readily cross.

Chelidonifoliae. This group consists of two undoubtedly perennial species so curiously alike as regards rootstocks, stems, foliage, and flowers, that they are only separable by means of their ripe capsules. Yet as regards the capsules they differ greatly, for $M$. chelidonifolia has an ovate capsule with a distinct style, and a stigma with decurrent contiguous lobes like those of every species except the species in the group Grandes, while M. Oliveriana has a sessile stigma with radiating divaricate lobes exactly as in $M$. integrifolia and $M$. punicea, or in Cathcartia villosa. The capsule, too, is in shape identical with that of Cathcartia villosa, differing only in opening by short apical pores instead of opening by complete separation of the valves from the placental ribs.

The conditions which obtain in English gardens are not always those most suitable for the development of the species of Meconopsis. This applies more particularly to the Himalayan species, some of which suffer so greatly from winter fogs and from moisture lodging in the crown that they die outright. It is possible to protect them to some extent by placing sheets of glass in a slanting position above the crowns.

As regards duration, the groups Cambricae, Bellae, Chelidonifoliae are perennial. The other groups are monocarpic as a rule, the Anomalae being indeed annual. But within the group Aculeatae we find that $M$. aculeata is sometimes, and within the group Grandes that $M . g r a n d i s$ is, as a rule, polycarpic. Among the monocarpic groups we find that while as a rule, though this is not without its exceptions, the flower follows a year from seed and the leaves of the crown die during the winter which intervenes, in the group Robustae the plants do not flower till the second year from seed, and the leaves of the crown persist during the two winters which intervene. But the question of duration can hardly be said to be settled for the genus by experience in horticulture under conditions admittedly unlike those to which the plants are naturally subjected. When it is seen that in the case of two, $M$. aculeata and $M$. grandis, a species may on occasion be either 
monocarpic or polycarpic, it is permissible to inquire whether this habitcharacter is necessarily inherent. It may be conditioned by the environment, and be an accidental, not an essential feature.

As regards habit, as apart from duration, the species of Meconopsis fall into three main series. The first of these includes the species with slender non-scapose, sparingly branched, leafy stems. In facies the species of this series agree well. As regards duration they vary, for the series includes the only annual group the Anomalae, and two of the definitely perennial groups the Cambricae and the Chelidonifoliae. This series includes the species that are outliers from the main body of the genus, the Californian Anomalae and the European Cambricae; it also includes the only group belonging to the main body of the genus, the Chelidonifoliae, of which one member ( $M$. Oliveriana) extends to central China. The second main series includes those species with stout non-scapose, much-branched, leafy stems. It corresponds to a single group, the Robustae, the members of which are monocarpic, flower in the second year from seed, and have, during winter, persistent leafy crowns. The third series includes those species with scapose unbranched stems or with no stems at all. As a rule the species are monocarpic, flower in the first year from seed, and have non-persistent leafy crowns. This series is, however, less uniform than the other two series, for there are some exceptions to the general rule. Thus M. bella, the only species of the group Bellae, and $M \cdot$ grandis, one of the species of the group Grandes, are uniformly perennial like the Cambricae and the Chelidonifoliae of the first series, and have persistent crowns like the Robustae of the second series. Among the Aculeatae too, $M$. aculeata is occasionally polycarpic. $M$. bella, besides being polycarpic and having persistent leafy crowns, differs from other species of the genus in sometimes not flowering till after several years from seed. This appears also to be probably the case with $M$. discigera of the group Torquatae, but this group is as yet inadequately known from the cultural point of view.

\section{Distribution.}

The distribution of the various species of Meconopsis, so far at least as our knowledge at present goes, is very local. This is in keeping with our knowledge of the species of other Alpine genera. The species at all widely spread are $M$. cambrica, which extends from the Pyrenees to Britain; $M$. horridula which occurs throughout the greater part of Tibet, and extends through some of the passes into the highest valleys of the eastern Himalaya and western China; $M$. aculeata, which extends along the north-western Himalaya from Kashmir to Kumaon; $M$. simplicifolia, which extends from Nepal to Chumbi, and crosses the passes into southern Tibet; $M$. paniculata, which extends from Nepal to Bhutan; $M$. Wallichii, which extends from Sikkim to Chumbi and reappears in Szechuen; and 
$M$. integrifolia, which extends from Yunnan to Kansuh and passes into central Tibet. In the subjoined table the facts of distribution are more succinctly shown.

Geographical Distribution of the Species of Meconopsis.

\begin{tabular}{|c|c|c|c|c|c|c|c|c|c|c|c|c|c|c|c|c|}
\hline & \multirow[b]{2}{*}{ Species. } & \multirow{2}{*}{$\begin{array}{l}\dot{0} \\
\text { о } \\
\dot{\Xi} \\
\text { | } \\
\dot{3}\end{array}$} & \multicolumn{6}{|c|}{ Himalaya. } & \multicolumn{3}{|c|}{ Tibet. } & \multicolumn{4}{|c|}{ China. } & \\
\hline & & & 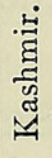 & 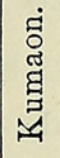 & $\begin{array}{l}\overrightarrow{\tilde{J}} \\
\ddot{\ddot{u}} \\
\not{z}\end{array}$ & 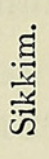 & है & 氙 & 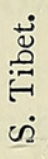 & 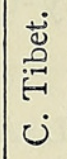 & 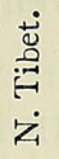 & 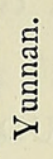 & 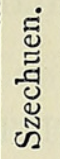 & 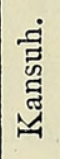 & 呇 & \\
\hline Meconopsis & s cambrica & $x$ & - & - & - & - & - & - & - & - & - & - & - & - & - & - \\
\hline ," & heterophylla & - & - & - & - & - & - & - & - & - & - & - & - & - & - & $\bar{x}$ \\
\hline ," & crassifolia. & - & - & - & - & - & - & - & - & - & - & - & - & - & - & $x$ \\
\hline , & aculeata. . & - & $x$ & $x$ & - & - & - & - & - & - & - & - & - & - & - & - \\
\hline ", & simuata. & - & $\overline{-}$ & - & - & $x$ & $\overline{-}$ & $x$ & - & - & $\overline{-}$ & $\bar{x}$ & $\bar{x}$ & - & - & - \\
\hline ", & horridula: & $\overline{-}$ & $\overline{-}$ & - & - & $\bar{x}$ & $\bar{x}$ & $\overline{-}$ & $\bar{x}$ & $\bar{x}$ & $\bar{x}$ & $\underline{x}$ & $\begin{array}{l}x \\
x\end{array}$ & $\bar{x}$ & $\overline{-}$ & - \\
\hline , & lancifolia. & - & - & - & - & - & - & - & - & - & - & $x$ & - & - & - & - \\
\hline " & Henrici. & - & - & - & - & - & - & - & - & - & - & - & $x$ & - & - & - \\
\hline ," & primulina & - & - & - & - & - & $x$ & $x$ & - & - & - & - & - & - & - & - \\
\hline$"$ & Delavayi & - & - & - & - & - & - & - & - & - & - & $x$ & - & - & - & - \\
\hline ", & bella. & - & - & - & - & $x$ & - & - & - & - & - & - & - & - & - & - \\
\hline ", & integrifolia & - & - & - & - & - & - & - & - & $x$ & - & $x$ & $x$ & $x$ & - & - \\
\hline ", & pseudointegrifolia & - & - & - & - & - & - & - & $x$ & - & - & - & - & - & - & - \\
\hline " & grandis . & - & - & - & - & $x$ & - & - & - & - & - & - & - & - & - & - \\
\hline$"$ & simplicifolia : & - & - & - & $x$ & $x$ & $x$ & $x$ & $x$ & - & - & - & - & - & - & - \\
\hline ," & quintuplinervia & - & - & - & - & - & - & - & - & - & $x$ & - & - & $x$ & - & - \\
\hline . & punicea & - & - & - & - & - & - & - & - & - & $x$ & - & $x$ & - & - & - \\
\hline " & torquata & - & - & - & - & - & - & - & $x$ & - & - & - & - & - & - & - \\
\hline " & discigera & - & - & - & - & $x$ & - & - & - & - & - & - & - & - & - & - \\
\hline ", & superba.. & - & - & - & $\bar{x}$ & - & $\bar{x}$ & $x$ & - & - & $\bar{z}$ & $\overline{-}$ & $\overline{-}$ & - & & - \\
\hline$"$ & paniculata. & $\overline{-}$ & $\overline{-}$ & $\bar{x}$ & $x$ & $x$ & $x$ & $x$ & $\overline{-}$ & - & $\overline{-}$ & - & $\bar{z}$ & $\bar{z}$ & $\overline{-}$ & - \\
\hline ” & $\begin{array}{l}\text { rotusta } \\
\text { napaulensis }\end{array}$ & - & - & $\underline{-}$ & $x$ & $x$ & - & - & - & - & - & - & - & - & - & - \\
\hline " & Wallichii . & - & - & - & - & $x$ & $x$ & $x$ & - & - & - & - & $x$ & - & - & - \\
\hline ," & chelidonifolia. & - & - & - & - & - & - & - & - & - & - & - & $x$ & - & - & - \\
\hline " & Oliveriana. & - & - & - & - & -. & - & - & - & - & - & - & $x$ & - & $x$ & - \\
\hline & & I & 1 & 2 & 3 & 9 & 5 & 6 & 4 & 2 & 3 & 4 & 8 & 3 & I & 2 \\
\hline
\end{tabular}

Meconopsis is very largely an alpine genus, there being only three species to which the term cannot be applied. These are the three that, by their distribution, are geographically furthest removed from the main body of the genus, viz.:- the West European M. cambrica, and the Californian $M$. heterophylla and $M$. crassifolia. These three are not even sub-alpine; they do not occur above 2,500 feet.

Of the Himalo-Chinese and Tibetan species, on the other hand, none come below 7,500 feet, and the only ones that ever appear to deserve being considered sub-alpine are $M$. robusta in Kumaon, M. Oliveriana in Hupeh, and $M$. quintuplinervia in Kansuh. All three species named, however, also reach truly alpine altitudes. The great bulk of the genus is to be found only at or above 10,000 feet; few of them indeed occur quite so low 
down as this, II,000-I3,000 feet being the usual range. Three of the species go as high as I6,000 feet, one of these, $M$. horridula, goes beyond 17,500 feet.

While, however, Meconopsis is essentially an alpine genus, it differs from many alpine genera in not being at the same time an Arctic one. It is not only confined to the northern hemisphere, but is restricted to a curiously narrow belt in that hemisphere. Of the twenty-seven species no fewer than twenty-two are confined to the zone between $25^{\circ}$ and $30^{\circ}$

\section{Altitudinal and Latitudinal Distribution of the SPECIES OF MECONOPSIS.}

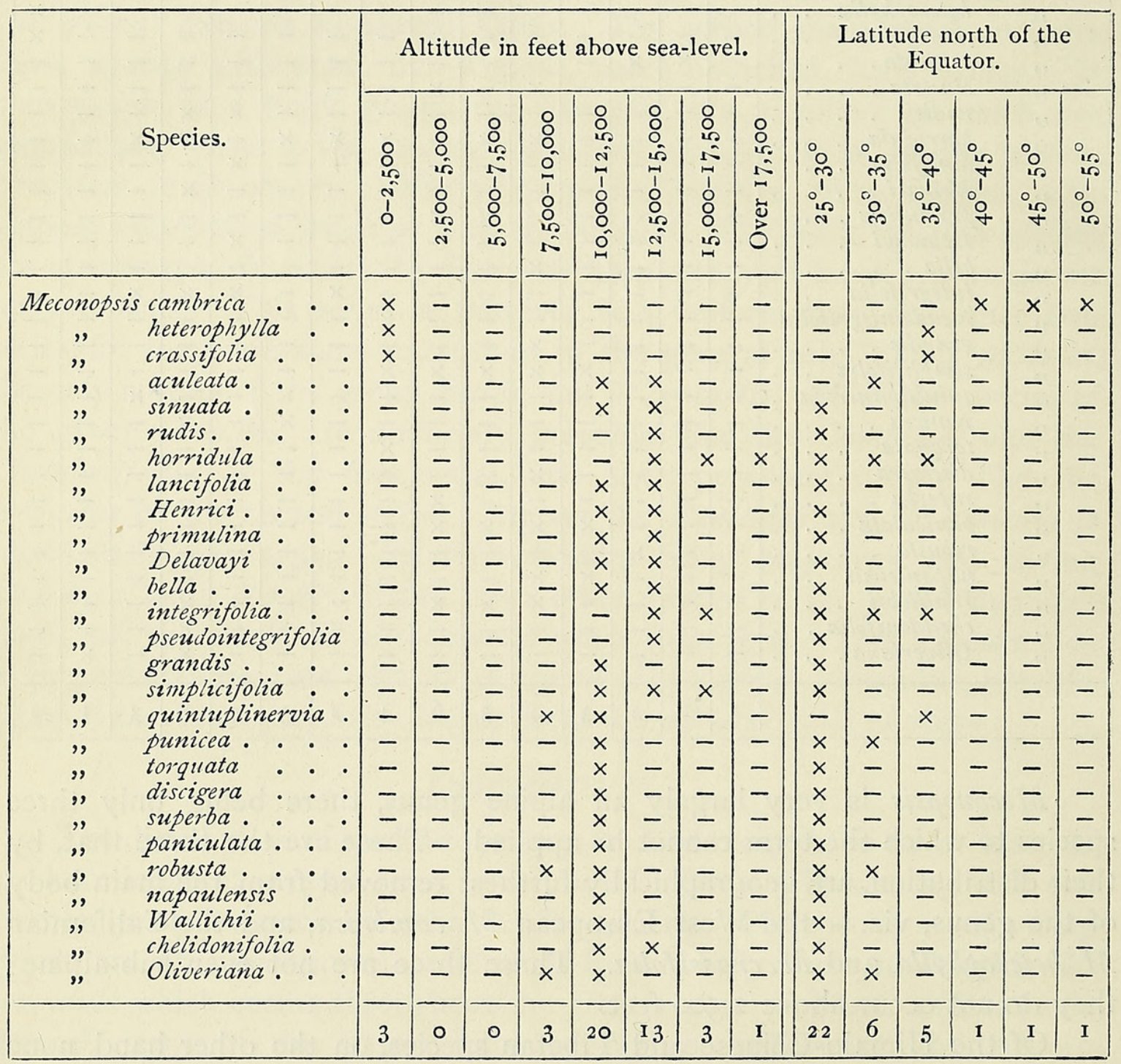

lat. N.; only six are found between $30^{\circ}$ and $35^{\circ}$ lat. N. ; and of the Asiatic species only three extend into the zone between $35^{\circ}$ and $40^{\circ}$ lat. $\mathrm{N}$. Of these only two, $M$. horridula and $M$. integrifolia, appear to occur in all three zones. 
The Californian species are confined to the $35^{\circ}$ to $40^{\circ}$ lat. N. zone, so that they do not extend the genus further to the north than do the Asiatic species. The European species $M$. cambrica, however, is exceptional in the genus in this as in other distributional characteristics, for it extends through more than $12^{\circ}$ of latitude, and occurs in the zones $40^{\circ}$ to $45^{\circ}, 45^{\circ}$ to $50^{\circ}$, and $50^{\circ}$ to $55^{\circ}$.

The tables foregoing show the facts of distribution as regards altitude and latitude in a more compact form.

Taken as a whole the facts of distribution as regards Meconopsis seem to indicate that, however advisable it may be to treat the flora of central and eastern China as distinct from that of India or even of Indo-China, the alpine flora of western China is essentially the same as that of the Himalayas.

It is highly probable that our acquaintance with this genus is as yet far from complete. Our knowledge of the high Himalayan valleys is doubtless fairly adequate so far as the region from Kashmir to Kumaon is concerned, and it is hardly to be anticipated that any species of Meconopsis remains undiscovered between lon. $73^{\circ}$ and lon. $82^{\circ}$ E. But as regards Nepal we know nothing of the high alpine vegetation save within a narrow segment near the $85^{\text {th }}$ meridian, which has been investigated by Wallich and Scully. Thanks to the energy of Sir J. D. Hooker, and to the efforts of Sir G. King, a small section of the eastern Himalaya between the 88th and 89th meridians has been as fully explored as any portion of the north-west Himalaya, with the result that this narrow strip has yielded no fewer than eleven species, of which seven, so far as we know, are peculiar to this limited belt. Some of these seven, like $M$. grandis, $M$. discigera, and $M$. bella, have only been found in the extreme west of the belt, and in all likelihood extend westward into unexplored Nepal; others, like $M$. superba and $M$. primulina, have only been found in the extreme east of the same narrow strip, and equally probably will be found to extend eastward into Bhutan. Between the $99^{\text {th }}$ and the $105^{\text {th }}$ meridians, from $25^{\circ}$ to $40^{\circ}$ lat. N., we have a belt of country which, thanks to the efforts of French missionaries in the south and centre, and of Russian explorers in the centre and north, supplemented as regards the centre by those of English travellers, has been tolerably investigated. This belt has also yielded eleven species, of which again seven, so far as we know, are peculiar. Of the alpine vegetation of the Himalayan region between the 89th and the 99th meridians we know practically nothing; and of the Tibetan region behind and to the north we only know that, out of four species of Meconopsis which it has so far yielded, two, $M$. torquata from the Kyi-chu valley and $M$. pseudointegrifolia from the Ra-chu valley, are distinct from any species recorded from either of the belts of relatively well-explored country alluded to. If all the circumstances are considered we seem entitled to anticipate that the 
conditions in the Himalayan country still to be explored are similar to those known to prevail in the portions as to which we already possess some information. If this should prove to be really the case we may expect to find that in the genus Meconopsis there are possibly some forty distinct forms.

\section{PROPERTIES.}

The properties of the species of Meconopsis are obscure. According to Don the root of $M$. paniculata is poisonous; the statement must obviously have been derived from a note by Wallich, and no doubt represents what Wallich was told by native collectors in Nepal. According to Hooker and Thomson, the natives of Sikkim are of the same belief as regards $M$. Wallichii, and according to Stewart the natives of Chamba think the same of $M$. aculeata. O'Shaughnessy, however, found that $M$. aculeata did not have much effect on lower animals, and although Honigberger has included this species among his officinal plants of Kashmir, he only remarks that it is 'said to be' narcotic, and indicates its use in cases of 'troubled sight.' Dymock, Warden, and Hooper have examined the roots of $M$. Wallichii chemically, but impute to it neither deleterious nor useful properties. In the 'Dictionary of the Economic Products of India,' v. I 97, 198 (I891), Watt has been unable to add any further information on the subject. Watt's remarks as to the medicinal properties imputed to $M$. nipalensis belong, it should be noted, to $M$. aculeata. They are derived from Honigberger and refer to Kashmir. In the first place neither the true $M$. napaulensis nor $M$. paniculata (the plant which Watt terms $M$. nipalensis) occurs in Kashmir ; moreover, Honigberger gives a figure of the plant intended by him as $M$. nepalensis. This figure is a good representation of the spiny, blue Poppy of Kashmir, $M$. aculeata.

\section{MECONOPSIS, ViG.}

Hist. Pav. Diss., 20 (I8I4); DC. Syst., ii. 86, Stylophoro excl. (I82I) ; Bernh., Linnaea, viii. 462 (I833) ; Endl., Gen., 836 (I84I) ; Benth. \& Hook. f., Gen. Pl., i. 52 (I862) ; Baill., Hist. des Plantes, iii. I40 (1872); Prantl \& Kundig, Nat. Pflanzenfam., iii. 2, I4I (I889).

Sepala 2. Petala nunc 4, nunc 5-9. Stamina $\infty$. Ovarii placentae 4- $\infty$ nerviformes vel plus minusve intrusae; stylus saepissime distinctus, raro obsoletus; stigmatis clavati vel depresso-dilatati lobi decurrentes contigui vel radiantes divaricati placentis oppositi. Capsula ovoidea, oblonga vel rarissime anguste cylindracea vertice saepius in stylum sensim attenuata, aliquando in discum astigmaticum circa basin styli explanata, valvis brevibus placentas styloque persistentes nudantibus dehiscens. Semina scrobiculata raphe cristata vel nuda.-Herbae saepissime monocarpicae nonnunquam tamen perennantes succo flavo. Folia integra vel 
lobata vel rarissime dissecta. Flores saepius longe pedunculati singuli vel in cymas racemiformes, vel raro paniculatas rarissime umbelliformes dispositi, speciosi, alabastris nutantibus.

Species adhuc recognitae 27 quarum $I$ in Europa occidentali, 2 in America boreali-occidentali, 10 in China, 2 in Tibetia, 12 in Himalaya crescunt ; forsan tamen ad 20 reducendae.

Genus in sectiones 2, sectiones iterum in greges naturales 9 commode dividuntur, scil. :-

§ Eumeconopsis. Glabrae vel aculeis setis pilisve simplicibus plus minusve obsitae.

Caules graciles ramosi; folia caulina pinnatipartita radicalia aequantia vel superantia :--

Capsula vertice sensim in stylum attenuata; perennantes

Capsula vertice quasi in discum astigmaticum explanata; annuae

I Cambricae.

बा Anomalae.

Caules scapiformes simplices, vel caules $\circ$; folia caulina radicalibus minora vel o:-

Plantae aculeis rigidis pungentibus ubique armatae

9ा Aculeatae.

Plantae glabrae vel sparse hirsutae setosaeve, inermes :-

Folia integra ; plantae monocarpicae

Folia dissecta ; plantae polycarpicae

Tा Primulinae.

I Bellae,

$\S \S$ Polychaetia. Setis pilisve barbellatis ubique plus minusve indutae.

Caules scapiformes simplices, vel caules 0 ; folia plerumque vel omnia radicalia subintegra :-

Capsula haud discigera; stigma depresso-dilatatum lobis radiantibus divaricatis

I) Grandes.

Capsula vertice in discum lobatum astigmaticum explanata; stigma clavatum lobis decurrentibus contiguis

I Torquatae,

Caules ramosi ; folia varie lobata vel pinnatifida, caulina numerosa :-

Caules robusti ; flores sat numerosi ; plantae monocarpicae

Caules graciles; flores pauci; plantae polycarpicae

I Robustae.

बा Chelidonifoliae.

\section{Clavis specierum.}

Setis vel pilis vel aculeis simplicibus obsitae vel fere omnino glabrae :-

Caules graciles ramosi ; folia caulina pinnatipartita radicalia aequantia vel superantia :-

Capsula vertice sensim in stylum attenuata; flores concolores lutei ; perennans

I. cambrica.

Capsula vertice quasi in discum astigmaticum explanata ; flores lateritii purpureoocellati ; annuae :-

Folia caulina internodis breviora; capsula angusta valvis $4-5$

Folia caulina internodis longiora; capsula lata valvis 6 -10

2. heterophylla.

3. crassifolia. 
Caules scapiformes simplices, vel caules o; folia caulina radicalibus minora vel o; flores coerulei :-

Plantae aculeis pallidis rigidis pungentibus ubique armatae :-

Folia distincte lobata; petala 4 ; torus vix incrassatus :-

Folia pinnatipartita ; capsula ovata

4. aculeata.

Folia sinuato-lobata; capsula elongato-obconica

5. sinuata.

Folia subintegra; petala saepissime $5-8$; torus sub capsulam late am pliatus :-

Folia caulina a basi ad medium cymae usque evoluta

6. rudis.

Folia caulina o:-

Flores in scapis I-floris interdum basi coalitis singuli

7. horridula.

Flores in cymas ebracteatas racemiformes dispositi

7 b. horridula, var. racemosa.

Plantae inermes setis pilisve simplicibus indutae, vel fere glabrae:-

Folia integra vel subintegra; plantae monocarpicae :-

Folia lanceolata :-

Flores in cymas ebracteatas racemiformes dispositi; petala 4

8. lancifolia.

Flores in scapis radicalibus singuli raro bini ; petala $5^{-8}:-$

Capsula statim in stylum abeuns; stigma integrum

Capsula circa basin styli papillis obsita; stigma 2-lobum

9. Henrici.

10. primulina.

Folia spathulato-oblonga; petala $5^{-8}$, scapis $\mathrm{I}$-floris

I I. Delavayi.

Folia pinnatisecta ; flores in scapis radicalibus singuli; petala saepissime 4 ; planta polycarpica

12. bella.

Setis pilisve barbellatis ubique plus minusve indutae :-

Caules scapiformes simplices, vel caules o; folia plerumque vel omnia radicalia subintegra :-

Capsula haud discigera; stigma depresso-dilatatum, lobis radiantibus divaricatis :-

Flores lutei; petala $5^{-8}$ :-

Caulis scapiformis; flores in cymas subumbelliformes $3-7$-floras dispositi ; stylus 0

Caulis o; flores in scapis radicalibus singuli; stylus elongatus

I3. integrifolia.

14. pseudointegrifolia.

Flores coerulei, purpurei vel punicei :-

Caulis scapiformis; flores in cymas subumbelliformes 3 -floras $\mathbf{x - 2}$ inferioribus sparsis interdum adiectis dispositi; petala $5-9$, stylus elongatus

Caulis o; flores in scapis radicalibus singuli :-

15. grandis.

Stylus elongatus; flores coerulei vel purpurei :-

Petala 5-8; capsula sparse setosa

Petala 4 ; capsula dense setosa

16. simplicifolia.

Stylus o; flores punicei; petala saepissime 4 , raro 8-9 $\quad$ I 8. punicea. 
Capsula vertice in discum lobatum astigmaticum glabrum explanata; caulis scapiformis ; flores in cymas multifloras subspicatas dispositi :-

Discus lobis integris; stylus perbrevis

19. torquata.

Discus lobis incisis ; stylus elongatus

20. discigera.

Caules ramosi ; folia radicalia distincte lobata vel pinnatifida ; caulina numerosa :-

Caules crassi ; flores plurimi saepissime paniculati ; plantae monocarpicae :-

Capsula ovata 8-I I-valvata ; stylus brevis basi distincte incrassatus :-

Flores albi ; folia caulina grosse dentata

21. superba.

Flores lutei :-

Folia caulina grosse dentata

Folia caulina pinnatifida

2. paniculata.

23. robusta.

Capsula oblonga $5-7$-valvata ; stylus elongatus ; folia caulina pinnatifida :-

Flores fusco-purpurei

24. napaulensis.

Flores coerulei

25. Wallichii.

Caules graciles ; flores pauci laxe cymosi ; plantae polycarpicae :-

Capsula ovata; stylus elongatus; stigma clavatum

26. chelidonifolia.

Capsula anguste cylindracea ; stylus o; stigma depresso-dilatatum

27. Oliveriana.

$\S$ I. EUmeConopsis. Herbae nonnunquam fere glabrae, sed saepius pilis, setis aculeisve simplicibus plus minusve obsitae ; capsula saepissime sensim in stylum attenuata, raro vertice circa basin styli quasi in discum astigmaticum explanata ; stigma clavatum lobis decurrentibus contiguis.Herbae saepius monocarpicae, nonnunquam equidem annuae; paucae tamen perennantes. Meconopsis $\$$ Meconopsis, DC. Syst. Veg., ii. 86 (1821); Prodr., i. 120 (I824).

I I. Cambricae, Prain. Inermes; perennantes ; caules elongati ramosi foliosi, folia pinnatifida glabra ; sepala parce pilosa ; flores lutei petalis 4 ; styli distincti; capsula glabra sensim in stylum attenuata. Chelidonifoliae, Prain, Journ. As. Soc. Beng., lxiv. 2. 3I3 (I895) partim.

1. Meconopsis cambrica, Vig. Rhizoma glabrum; folia ovatolanceolata, segmentis ovato-lanceolatis, lobis acutis, caulibusque glabra; sepala hirsuta; capsula ovata, stylo distincto. Vig., Hist. Pav. Diss., 48, fig. 3 (I8I4) ; DC. Fl. Fr., ed. 3, v. 586 (I8I5) ; Syst. Veg., ii. 87 (1821); Mem. Soc. Phys. Nat. Gen., i. t. 2, fig. I2 (I82 I) ; Prodr., i. I 20 (1824); Lindl., Syn. Brit. Fl., ed. I, I 7 (I829) ; Hook., Brit. Fl., ed. I, 256 (1830); Baxt., Brit. Bot., i. t. 54 (1834) ; Mackay, Fl. Hibern., I4 (1836); Bab., Man. Brit. Bot., ed. I, I2 (1 843 ) ; ed. 9, I9 (1904) ; Deakin, Florigr. Brit., ii. 754 , t. $856(1845)$; Syme, Eng. Bot., ed. 3, t. 63 (1863); Moore and More, Cybele Hibern., ed. I, I3 (I866); Hook. f., Stud. Fl. I6 (1870); Willk. \& Lange, Fl. Hispan., iii. 873 (I880) ; H. C. Wats., Topog. Bot., ed. 2, 23 (1883) ; Colmeiro, Enum. Pl. Hispan. Lusit., i. IOI (I885); Coste, Fl. Fr., i. 6I (I90I) ; Flora and Sylva, iii. 82 (I905). Argemone Cambro Britanica lutea, Parkins., Theatr. Bot., 369, 370 (1640). A. cambrica, 
Desp., Dict. Sci. Nat., ii. 48 I (18I6) ; Nouv., Dict. Hist. Nat., ii. 462 (18I6). Papaver cambricum perenne flore sulphureo, Dill., Hort. Elth., 3co, t. 223 (I732). P. cambricum, Linn., Sp. P1., ed. 1, 508 (I753) ; Hill, Herb. Brit., ii. 235 , t. I54 (I770); Sowerby \& Sm., Eng. Bot., ed. I, t. 66 (1790); Sm., Fl. Brit., i. 568 (1800); Poir., Encyc. Meth., v. I17 (1804); DC., Fl. Fr., ed. 3, iv. 633 (1805); Hook., Fl. Scot., i. I68 (1821). Cerastites cambrica, S. F. Gray, Nat. Arr. Brit. P1., ii. 704 (1821). Stylophorum cambricum, Spreng., Syst., ii. 570 (1825) ; Steud., Nomencl., ed. 2. 650 (I84I).

Europa occidentalis. In sepibus et dumetis umbrosis a Pyrenaeis ad Hiberniam, Cambriam Cumbriamque usque; nunquam supra 2000 p.s.m.

The well-known Welsh Poppy, familiar as a wild plant in western France and England and in Ireland: often in gardens and occasionally naturalized in parts of Britain other than those in which it is a native species. Polycarpic. Occasionally in cultivated plants there are more than four petals.

As a group the Cambricae, which includes a single form, is very natural. In habit it agrees with only one other group, the Chelidonifoliae, in which at one time the writer proposed to include M. cambrica. Among the Papaveraceae as a whole this group most resembles the section Stylophorum of the genus Chelidonium; so close is the affinity that De Candolle and others have treated Stylophorum and $M$. cambrica as congeneric.

T 2. Anomalae, Prain, Journ. As. Soc. Beng., 1xiv. 2. 3I 3 (I895). Inermes; annuae ; caules elongati ramosi foliosi ; folia irregulariter pinnatipartita glabra; flores lateritii vel aurantiaci purpureo-ocellati petalis 4; styli distincti ; capsula glabra circa basin styli quasi in discum astigmaticum explanata.

2. Meconopsis heterophylla, Benth. Caules apicem versus laxe ramosi ; folia pauca herbacea radicalia evanida caulina internodis breviora ; capsula anguste turbinata saepissime valvis 4-5 quadrante summo aperta (P1. XXIV, Fig. 9). Benth. in Trans. Hort. Soc., ser. II, i. 408 (1835); Torr. \& Gray, Fl. N. Amer., i. 6r (1838); Hook. \& Arn., Bot. Beechey Voy., 320 (1840) ; Hook., Ic. Pl., t. 732 (1845); Torr. in Pacif. Rail. Rep., iv. 64 (I857); Bot. U. S. Mex. Bound. Surv., 3I (I858); Bot. Calif., i. 22 (I 888); Rattan, Pop. Calif. Fl., ed. 8, 2I (I888); Pars. \& Buck, Wild Fl. Calif., I29 (I897) ; Hook., Bot. Mag., t. 7636 (I899); Gard. Chron., ser. III, xxix. 4I2, fig. 55 (I90I); Abrams, Fl. Los Ang., I62 (I904); Flora and Sylva, iii. 82 (1905). Stylophorum heterophyllum, Steud., Nomencl., ed. 2, ii. 65 ० (184I). Papaver heterophyllum, Greene, Pittonia, i. 168 (I888); Fl. Francisc., 28I (I892); Man. Bot. San Francisc. Bay, 9 (I894); Jepson, Fl. West Mid. Calif., 209 (1901).

AMERICA BOREALI-OCCIDENTALIS. California; in cultis, an semper? Apparently an agrestal state of the next form. 
3. Meconopsis crassifolia, Benth. Caules a basi ramosi ; folia satis numerosa carnosula radicalia subpersistentia caulina internodis longiora; capsula late turbinata saepissime valvis 6 vel pluribus apice tantum brevissime aperta (Pl. XXIV, Fig. IO). Benth. in Trans. Hort. Soc., ser. II, i. 408 (1835); Torr. \& Gray, Fl. N. Amer., i. 6I (I838) ; Hook. \& Arn., Bot. Beechey Voy., 320 (1840). Stylophorum crassifolium, Steud., Nomencl., ed. 2, ii. 650 (I84I). Papaver crassifolium, Greene, Man. Bot. San Francisc. Bay, 9 (I894). P. heterophyllum, var. crassifolium, Jepson, Fl. West Mid. Calif., 209 (I901).

AMERICA BOREALI-OCCIDENTALIS. California; in pratis, dumetis agrisque.

Doubtfully separable from the preceding.

The Anomalae constitute a natural group, distinguished from all other groups in being not only monocarpic but annual, and in having the petals marked by a dark basal blotch; in the other known species the petals are concolorous. The foliage is more deeply divided than in any group except the Bellae. These two groups, the Bellae and the Anomalae, further agree in that the apices of the valves by which the capsules dehisce do not quite extend to the base of the style, and so leave the vertex of the capsule solid. In the Bellae the solid portion surrounding the base of the style is convex and is not very extensive. In the Anomalae, however, this solid part of the capsule is as wide as the capsule itself, is almost flat, and resembles the disk of a true Papaver except in being astigmatic. This flattened vertex, however, is hardly a disk in the sense of the term as used in the case of a Papaver like $P$. somniferum or $P$. dubium, because the margin ends at, but does not project beyond, the margins of the valves.

The question whether there are more species than one in the group Anomalae has been often discussed but has not been satisfactorily settled. An examination of the material in the herbarium at Kew shows that there are certainly two forms corresponding more or less closely to the types of Bentham's two species. The remarks of such competent authorities as Greene and Jepson indicate that in the field also two forms are more or less distinguishable. But how far the forms distinguished by Greene and Jepson correspond to the species defined by Bentham, and which form as recognized in the field in California corresponds with either name given by Bentham, is not so clear as could be wished. The difficulty was explained by Greene in I89I (Flor. Francisc. 28I) at which time he was doubtful whether his two forms represented more than states of one species differing in facies in consequence of their environment. By $\mathbf{1} 894$ Greene had become satisfied (Bot. San Francisc. Bay, 9) that, of the two forms recognized by him, the one from wooded slopes corresponds to Bentham's $M$. heterophylla, the one from dry fields to $M$. crassifolia. Jepson in 190I (Flor. West Mid. Calif. 209) has followed Greene's discrimination of 1894 , though he treats the two forms as merely varieties of one species. Unfortunately with the specimens at Kew which agree with the type of $M$. heterophylla we have in no instance any note as to habitat, while of the specimens that agree with $M$. crassifolia some are from grassy banks, some from shaded cañons, some from 
fields of growing grain. At the same time some of the specimens at Kew which accord well with $M$. crassifolia have been so named by competent Californian botanists; others, however, have been named $M$. heterophylla, with which they do not so well agree. The writer is, therefore, led to suspect that within what must in the herbarium be treated as $M$. crassifolia there may be two forms or conditions recognizable in the field, and that the true $M$. heterophylla is either a further segregate from one of these forms or is not accounted for in recent Californian botanical literature. This last possibility is suggested by the remark made by Greene in $\mathbf{I} 8 \mathbf{9} \mathbf{I}$ that he had been unable to find in California a plant with capsules like those figured by Hooker (Ic. Plant., t. 732). Yet this figure represents very accurately a plant from California which the writer agrees with Sir W. Hooker in referring to the true M. heterophylla, Benth. Under the circumstances all that it is possible to do is to give, as has been done above, the salient characters of Bentham's two plants and to leave them for the moment as Bentham left them. The true relationship of the two must be settled in the field, and a final decision can only be come to by our colleagues in California. It may, however, be observed that while Greene has decided that there are two species, Jepson has considered Greene's two species as no more than varieties of one, and Rattan has concluded that there is but one Californian Meconopsis. Sir J. Hooker, after examining the material at Kew, which includes Bentham's types of $M$. helerophylla and of $M$. crassifolia, has expressed the same opinion as Rattan, and the writer is personally inclined to adopt the view of Rattan and Hooker. Indeed, if one could judge from herbarium specimens only, the natural conclusion would seem to be that in Bentham's $M$. crassifolia we see the normal state of this solitary species, whereas in $M$. heterophylla we have an agrestal condition of the same plant with quickly disappearing radical leaves, elongated internodes, a weak, slender, often straggling, stem and smaller flowers and fruits, owing to the plant having been 'drawn up' amorig tall grass or grain. This conclusion is, however, partially traversed by the experience of Greene and Jepson as recorded in their respective works and by the experience of various collectors as recorded in their field-notes.

One difficulty in connexion with the settlement of the question is that there are no ripe capsules on the original specimens on which Bentham based $M$. heterophylla and $M$. crassifolia. The drawing of the fruit of the former plant (Pl. XXIV, Fig. 9) is taken from a specimen identified by Sir W. Hooker with $M$. heterophylla, Benth. There is hardly room for doubt that this identification is correct. The drawing of the fruit of the latter (Pl. XXIV, Fig. IO) is from a specimen collected by C. F. Baker, and identified by Greene with Bentham's $M$. crassifolia; here again the identification seems certainly accurate.

In European gardens, so far as can be ascertained, only one species of Meconopsis from California can be recognized.

I 3. Aculeatae, Prain, Journ. As. Soc. Beng., 1xiv. 2. 3 I3 (I 895 ). Armatae; saepius monocarpicae aliquando tamen perennantes; cåules saepissime evoluti simplices scapiformes raro $\circ$; flores coerulei petalis nunc 4, nunc $5^{-8}$; styli distincti ; capsula echinata sensim in stylum attenuata. 
4. Meconopsis aculeata, Royle. Folia sparse aculeata lineari-oblonga lanceolatave irregulariter pinnatifido-lobata lobis varie lobulatis; flores in cymas racemiformes dispositi, pedicellis fere omnibus bracteatis; petala 4; capsula ovata stylo duplo longior; torus vix ampliatus. Royle, Ill. Him., 67 , t. I5 (I839); Walp., Rep., i. IIO (I842); O’Shaughnessy, Beng. Dispens., I 84 (I842) ; Beng. Pharm., 5 (I844) ; Hook. f. \& Thoms., Fl. Ind., 253 (I 855) ; Walp., Ann., iv. I 7 I (1857); Klotzsch, Reis. Pr. Waldem., 129 (I862) ; Hook., Bot. Mag., t. 5456 (I 864); Stewart, Panjab Plants, 9 (1869); Hook. f. \& Thoms., Fl. Brit. Ind., i. I18 (1872); Prain, Journ. As. Soc. Beng., lxiv. 2. $3^{14}$ (I895); Collett, Flor. Siml., 23 (I902); Flora and Sylva, iii. 82 (I905); Strachey, P1. Kumaon, 8 (I906). M. GulielmiWaldemari, Klotzsch, Reis. Pr. Waldem., I 29, t. $3^{6}$ (I862). M. napaulensis, Jacquem. ex Prain, Journ. As. Soc. Beng., lxiv. 2. 3I4 (I 895$)$; Falc. ex Prain, loc. cit. (1895). M. nepalensis, Honigberger, Thirty-five Years in the East, ii. t. 15 (1852). Stylophorum nepalense, Honigberger, Thirty-five Years in the East, ii. 352 (1852).

Himalaya occidentalis. A Kumaon ad Kashmir usque; in pratis alpinis, 10-I 5,000 p. s. m.

Representative in the North-West Himalaya of the Tibetan M. horridula. Differs from $M$. rudis and $M$. horridula in the lobed leaves and narrow torus, from $M$. sinuata in the shorter capsule. Well known in cultivation and usually monocarpic. At Edinburgh plants have, however, flowered in three successive seasons; at Kew one plant has flowered in two successive seasons.

5. Meconopsis sinuata, Prain. Folia sparse aculeata lineari-oblonga lanceolatave margine irregulariter lobata sinuatave lobis integris ; flores in cymas racemiformes dispositi, pedicellis fere omnibus bracteatis; petala 4; capsula anguste obconica stylo 5-plo longior; torus vix ampliatus. Prain, Journ. As. Soc. Beng., lxiv. 2. 3 I4 (I895) ; Ann. Roy. Bot. Gard. Calcutta, ix. I. 5. t. 6 (I90I).

Himalaya orientalis. In Sikkim et Bhutan; in pratis alpinis, IO-I 3,000 p. S. m.

Representative in the Eastern Himalaya of the Tibetan $M$. horridula. Differs from $M$. rudis and $M$. horridula in the lobed leaves and narrow torus, from $M$. aculeata in the long capsule. Not yet known in cultivation. Probably monocarpic.

6. Meconopsis rudis, Prain. Folia sparse aculeata oblongo-lanceolata margine subintegra; flores in cymas racemiformes dispositi, pedicellis inferioribus bracteatis summis ebracteis; petala $5^{-8}$; capsula ovata stylo duplo longior; torus distincte ampliatus. M. racemosa, Franch., Bull. Soc. Bot. Fr., xxxiii. 390 (I886); Pl. Delavay., 4I (I889) nec Maxim. $M$. horridula, var. rudis, Prain, Journ. As. Soc. Beng., lxiv. 2. 314 (I895). M. simuata, var. Prattii, Prain, Journ. As. Soc. Beng., lxiv. 2. 3 I4 (1895). 
China aUstro-occidentalis. In Yunnan et Szechuen, in pratis alpinis, I $3-$ I 5,000 p. s. m.

Aculeata, spinis patentibus pallide stramineis sparse obsita. Rhizoma fusiforme. Folia radicalia pauca cito marcescentia caulina oblongo-lanceolata subacuta vel obtusa sensim in petiolum distinctum attenuata, laminis $8-10 \mathrm{~cm}$. longis, $2-3 \mathrm{~cm}$. latis, margine subintegris vel serratis utrinque viridibus sed subtus pallidiore, utrinque aculeatis, petiolis basi subvaginatis imis $3-5 \mathrm{~cm}$. longis, summis obsoletis. Caulis ad $40 \mathrm{~cm}$. usque altus, simplex, triente summo excepto foliosus, prope basin $\cdot 5^{-\mathbf{I}} \mathrm{cm}$. crassus cylindricus, triente imo excepto laxe floriferus, prorsus sparse aculeatus. Flores cymosi, pedicellis aculeatis $2-5 \mathrm{~cm}$. longis. Sepala oblongo-ovata extus densius aculeata. Petala $5^{-8}$, obovata oblongave, $3 \mathrm{~cm}$. longa, $\mathbf{I}-2 \mathrm{~cm}$. lata, pallide coerulea, glabra. Stamina $\infty$, pluriseriata, filamentis gracillimis discretis glabris. Ovarium e carpellis 4 compositum, densius aculeatum; stylus pyramidalis glaber $4 \mathrm{~mm}$. longus ; stigma oblongum 4-sulcatum; placentae intrusae; ovula plurima. Capsula ovata $6 \mathrm{~mm}$. longa, $5 \mathrm{~mm}$. lata, aculeata in toro explanato incrassato $5 \mathrm{~mm}$. lato insidens.Yunnan ; Likiang, I3,000 p.s. m., Delavay! Szechuen ; Tachienlu, I3-15,000 p.s. m., Pratt, 525! Soulie, 635! Wilson, 3162!

Representative in Yunnan and Szechuen of the Tibetan M. horridula. Differs from $M$. aculeata and $M$. sinuata in the subentire leaves and the enlarged torus; from $M$. horridula in having a smaller capsule and having the pedicels in the lower two-thirds of the racemose cyme bracteate. Not yet known in cultivation. Probably monocarpic.

7. Meconopsis horridula, Hook. f. \& Thoms. Folia densius aculeata lanceolata margine integra; flores in scapis rigidis dense aculeatis radicalibus discretis vel interdum basi coalitis singuli; petala saepius $5^{-8}$, nonnunquam 4; capsula ovata stylo duplo longior; torus late explanatus. Hook. f. \& Thoms., Fl. Ind., 252 (1855) ; Walp., Ann., iv. I7 I (I857) ; Hook. f. \& Thoms., Fl. Brit. Ind., i. I 8 (I872) ; Hemsl., Journ. Linn. Soc., $\mathrm{xxx} .108$, I34 (I894) ; Prain, Journ. As. Soc. Beng., lxiv. 2. 3I 3 (1895) ; Hemsl., Journ. Linn. Soc., xxxv. I64 (I902); Flora and Sylva, iii. 83 (I 905 ).

Tibet AUSTRALIS. In saxosis, supra I4,000 p.s. m. Himalaya ORIENTALIS. In Sikkim et Chumbi; in saxosis alpinis, supra I4,000 p. s. m.

Apparently a reduced state of the form next to be described. Not so far met with in European gardens. Apparently monocarpic.

Var. racemosa, Prain. Folia aculeata lanceolata margine integra vel subintegra; flores in cymas racemiformes dispositi pedicellis omnibus ebracteis vel raro pedicello imo tantum bracteato; petala 5-8; capsula ovata stylo duplo longior; torus distincte explanatus. Prain, Journ. As. Soc. Beng., lxiv. 2. $3^{\text {I } 3}$ (I 895). M. racemosa, Maxim., Bull. Acad. Petersb., xxiii. 310 (1876); Mel. Biol., ix. 7I3 (1876); Forbes \& Hemsl., Journ. 
Linn. Soc., xxiii. 34 (I886) ; Maxim., Fl. Tangut., i. 36, t. 9, figs. I-6, t. 23 , fig. 26 (1889); Flora and Sylva, iii. 84 (I 905).

Tibet. In locis saxosis late dispersa. Himalaya orientalis. In saxosis alpinis supra 14,000 p.s. m. in Sikkim et in Chumbi cum praecedenti rara. China. In saxosis alpinis supra 14,000 p. s.m. in Szechuen; in pratis alpinis in Kansuh.

Now established in European horticulture. Apparently monocarpic.

The Aculeatae as a whole form a natural group, most nearly related to the Primulinae. They differ from the latter group chiefly in being armed with rigid spines which replace the simple, rarely rigid and never pungent setae that are more or less characteristic of the Primulinae. They further differ in having, with the exception of $M$. horridula proper, well developed stems, whereas in the Primulinae, with the exception of $M$. lancifolia, we usually have simple $\mathrm{I}$-flowered scapes. At least a year appears to elapse between seed and flower in all the species of this group ; the crown of leaves dies down during the intervening winter. As a rule the plant dies after flowering, but in the case of $M$. aculeata individual plants are occasionally polycarpic.

The question how far the forms that compose the Aculeatae are distinct species is an open one. Hooker and Thomson (Fl. Ind., $2^{2}$ ) have suggested that the two forms which are most distinct in habit and appearance, $M$. aculeata and $M$. horridula proper, may be only varieties of one species. On the other hand, the two that are most nearly allied, $M$. horridula proper and $M$. horridula var. racemosa, have been treated by Maximowicz as distinct species (Mel. Biol., ix. 7I 3 and Fl. Tangut., i. 36 ). The more convenient and perhaps more natural treatment adopted here lies between these two extreme views.

If further reduction be necessary it may be suggested that there are only two somewhat variable species in the group; (I) $M$. aculeata, with $M$. simuata as a distinct variety differing in the degree of lobulation of the leaves and in the shape of the capsule ; and (2) M. horridula, including as distinct varieties $M$. racemosa and $M$. rudis. The characters separating the two widened species are the $5^{-8}$ petals, enlarged torus, and subentire leaves in $M$. horridula, the 4 petals, unexpanded torus, and more or less lobed leaves in $M$. aculeata.

T 4. Primulinae, Prain, Journ. As. Soc. Beng., lxiv. 2. 319 (1895). Inermes; monocarpicae ; caules saepissime brevissimi ; folia integra ; flores intense coerulei petalis saepissime $5-8$, raro 4 ; styli distincti; stigmata saepissime globoso-clavata, raro bifida; capsula glabra vel plus minusve setosa sensim in stylum attenuata.

8. Meconopsis lancifolia, Franeh. Folia caulibusque plus minusve setosa, lanceolata margine integra ; flores in cymas racemiformes dispositi, pedicellis ebracteis; petala 4; capsula anguste obconica stylo 4-plo longior. Franch. ex Prain, Journ. As. Soc. Beng., lxiv. 2. 3II (I895). Cathcartia lancifolia, Franch., Bull. Soc. Bot. Fr., xxxiii. 39 I (1886); Pl. Delavay., 43 (1889). 
CHINA OCCIDENTALIS. Yunnan; in pratis saxosisque alpinis, III 3,500 p. s. in.

Related to the next species, $M$. Henrici, very much as $M$. racemosa is related to $M$. horridula; perhaps, therefore, $M$. Henrici may ultimately have to be merged in this species. The specimens as yet reported appear, however, to have only 4 petals; those of $M$. Henrici almost all have more than 4 ; it is therefore, for the present, convenient to keep the two apart. Not yet introduced to European gardens. Apparently monocarpic.

9. Meconopsis Henrici, Bur. \& Franch. Folia caulibusque saepius parce nonnunquam tamen dense setosa, raro glabra, lanceolata margine integra; flores in scapis pseudoradicalibus singuli vel interdum gemini; petala 6-8 ; capsula anguste obconica stylo 4-plo longior. Bur. \& Franch., Journ. de Bot., v. I9 (I891). M. principis, Flora and Sylva, iii. 84 (I905).

China oCCIDENTALIS. Szechuen; in pratis saxosisque alpinis, I2I 4,000 p. s. m.

Sometimes quite glabrous, at other times sparingly strigose, and then very like $M$. primulina, or more or less beset with simple setae and then like $M$. lancifolia; occasionally densely clothed with rigid setae and rather like $M$. horridula: the setae, however, are not pungent. The occurrence of a second flower below the terminal flower of a scape is not infrequent; this circumstance strengthens the suspicion that $M$. lancifolia may be no more than an unusual state of a species of which $M$. Henrici is the usual form. The synonym $M$. principis used for the species in 1905 (Flora and Sylva, iii. 84) is the manuscript name originally employed by the late Mr. Franchet for the specimens subsequently described as M. Henrici. This has recently been introduced into European gardens, and promises to be a pleasing addition to horticulture. Apparently monocarpic.

10. Meconopsis primulina, Prain. Folia caulibusque parce strigosa lanceolata margine integra; flores in scapis pseudoradicalibus singuli; petala 6-8 ; capsula (matura ignota) anguste oblonga, glabra, vertice prope basin styli papillis obtusis induta; stigma 2-lobum. Prain, Journ. As. Soc. Beng., lxiv. 2. 319 (I895) ; Ann. Roy. Bot. Gard. Calcutta, ix. I. 3, t. 3 (I90I).

Himalaya ORIENTALis. Chumbi et Bhutan; in pratis saxosisque alpinis, I 2-I 4,000 p.s. m.

Very nearly allied to $M$. Henrici, and differs from that species only in having a distinctly 2-lobed stigma and in possessing two pairs of epaulette-like papillae suggestive of a rudimentary partial disk. Possibly the communication of larger suites of specimens may render it necessary to unite this plant to $M$. Henrici and to reduce both to $M$. lancifolia. In any case these three forms must be considered representative forms in three adjacent geographical areas. This form has not yet been introduced to European gardens. Apparently monocarpic.

11. Meconopsis Delavayi, Franch. Folia caulibusque glabra, sub- 
rhomboidea obtusa margine integra vel subtiliter repanda ; flores in scapis pseudoradicalibus singuli ; petala $5-8$, interdum 4 ; capsula (matura ignota) oblonga ; stylus brevis. Franch. ex Prain, Journ. As. Soc. Beng., lxiv. 2. 3I I (1895). Cathcartia Delavayi, Franch., Bull. Soc. Bot. Fr., xxxiii. 390 (I886); Pl. Delavay., 42 (I889).

China occidentalis. Yunnan; in pratis alpinis, 12,500 p.s. m.

This species is also nearly related to the preceding three forms, but differs from all of them in regard to its foliage. Not yet introduced to European gardens. Apparently monocarpic. Though very nearly glabrous, a few simple hairs are to be found on the scapes and on the leaves.

The Primulinae form quite as natural a group as the Aculeatae, to which they are most nearly allied, and with which they have already been contrasted. Here, again, it is an open question whether the forms that compose the group are really distinct species. It has been shown that there is room for suspecting that $M$. Henrici and $M$. lancifolia may only be different states of one species; it may equally well transpire that $M$. primulina is merely an abnormal form of the same. If this can be proved the Primulinae will contain but two species, (I) M. lancifolia, including $M$. Henrici and $M$. primulina, with lanceolate leaves, and (2) M. Delavayi, with subrhomboid leaves. Apparently the species of this group flower in the year following sowing, the leaves dying down during the intervening winter. So far as is known they are monocarpic and die after flowering.

9 5. Bellae, Prain, Journ. As. Soc. Beng., 1xiv. 2. 32 I (1895). Inermes; perennantes ; caules 0 ; folia pinnatisecta ; flores coerulei petalis 4-5; styli distincti; capsula vertice circa basin styli subito quasi in discum angustum convexum astigmaticum explanata.

12. Meconopsis bella, Prain. Folia scapisque glabra vel minopore setosa, 2-3-secta lobulis parvis; flores in scapis radicalibus singuli; petala 4, raro 5; capsula ovata vertice ultra valvarum apices circa basin styli solida ; stylus brevis. Prain, Journ. As. Soc. Beng., lxiii. 2. 82 (I 894); Journ. As. Soc. Beng., lxiv. 2. 32 I (I 895) ; Ann. Roy. Bot. Gard. Calcutta, ix. I. 3, t. 4 (I90I) ; Flora and Sylva, iii. 82. I66 (I905); Gard. Chron., ser. III, xl. I98, fig. 8I (I906).

Himalaya orientalis. Sikkim occidentalis, a finibus Nepaliae orientalibus prope, in rupibus alpinis, $12-14,000$ p.s. m.

A very distinct species; polycarpic; the leaves persist during the winter months. There is no disk, but the tips of the valves do not quite extend to the base of the style, so that the top of the capsule is intermediate in appearance between that of a typical Meconopsis and that of a species of the Californian group Anomalae. Unlike the other species of the genus, which affect open alpine hillsides or occur among alpine scrub or on the edges of woods, M. bella appears restricted to more or less vertical cliffs into whose clefts the stout rootstocks grow horizontally.

This species has for some years been in cultivation at Edinburgh and perhaps elsewhere. It has flowered at Edinburgh this year (I 906) for the first time. 
The Bellae as a group must be considered quite natural. Like the Primulinae, and still more like the Grandes in habit, this group differs from both in foliage. Sometimes more than two seasons elapse between seed and flower, and in this respect the group differs from the two groups mentioned.

$\S$ II. Polychaetia. Herbae inermes pilis vel setis barbellatis indumento stellato interdum interiecto plus minusve indutae ; capsula sensim in stylum attenuata vel stigmate sessili coronata, raro vertice circa basin styli in discum astigmaticum explanata ; stigma clavatum lobis decurrentibus contiguis vel depresso-dilatatum lobis radiantibus divaricatis.-Herbae saepius monocarpicae; paucae tamen perennantes. Meconopsis $\S$ Stylophorum, DC. Prodr., i. I2 I (I824) partim. Polychaetia, Wall. MSS. (gen.) ex Prain, in Journ. As. Soc. Beng., 1xiv. 2. 3 I6 (1895).

वा 6. Grandes, Prain, Journ. As. Soc. Beng., 1xiv. 2. 320 (I895). Caules - vel raro simplices scapiformes; folia integra vel subintegra plerumque vel omnia radicalia; flores pauci in scapis simplicibus aphyllis singuli vel ad apicem scapi fasciculatim foliosi in cymas umbelliformes, 3-7-floras dispositi, petalis 6-9, rarissime 4; styli saepius distincti, nonnunquam obsoleti ; stigmata depresso-dilatata lobis radiantibus divaricatis; capsula plus minusve appresse setosa in stylum sensim attenuata vel subito in stigmatis plicaturas extensa.-Herbae plerumque monocarpicae, singula tamen plane perennans.

13. Meconopsis integrifolia, Franch. Caulis scapiformis versus apicem fasciculatim foliosus, raro obsoletus ; folia integra ; flores in cymas umbelliformes 3 -7-floras dispositi, raro in scapo simplice I-floro flos singulus medianus; petala $5^{-8}$ lutea; stylus 0 ; stigma latissimum (Pl. XXIV, Figs. 7, 8). Franch., Bull. Soc. Bot. Fr., xxxiii. 389 (1886) ; Pl. Delavay., 4I (I889) ; Maxim., Fl. Tangut., 35, t. 9, figs. 7-12, t. 23, figs. 22-25 (I889); Hemsl., Journ. Linn. Soc., xxxv. I64 (I902); Gard. Chron., ser. III, xxxvi. 240 c. ic. (1904); Le Jardin, xviii. 328 (I904); Bot. Mag., t. 8027 (I905); Flora and Sylva, iii. I9 I c. ic. (1905). Cathcartia integrifolia, Maxim., Bull. Acad. Petersb., xxiii. 310 (1876); Mel. Biol., ix. 7 I3 (1876); Forbes \& Hemsl., Journ. Linn. Soc., xxiii. 34 (1886).

China occidentalis. In Kansuh, Szechuen, et Yunnan; in pratis alpinis, I $3^{-1} 5000$ p.s.m. TIBET CENTRALIS. In valle Gooring, 16,500 p. S. m.

Hemsley has suggested that the Tibetan specimen from the Gooring Valley, originally identified by him as $M$. integrifolia, may not really belong to this species. Lipsky and the writer have, however, felt satisfied after further examination of the material that Hemsley's original determination is accurate, though the note that the flowers are 'blue' is a lapsus calami, for the petals in the specimen referred to are yellow. As Hemsley and Bulley have independently pointed out, the plant figured as $M$. integrifolia by Bulley in Flora and Sylva, iii. $8_{3}$, is not 
this species. This handsome form is now thoroughly established in European alpine gardens, where it always is monocarpic.

14. Meconopsis pseudointegrifolia, Prain. Caulis 0 ; folia integra; flores in scapis simplicibus $\mathrm{I}$-floris singuli; petala 5 -8, lutea; stylus distinctus sursum incrassatus; stigma latum (Pl. XXV). M. integrifolia, Bulley in Flora and Sylva, iii. 80 c. ic. (1905) nec Franch.

Tibet AUSTRALI-OCCIDENTALIS. Kham; in pratis alpinis, III 2,000 p. s. m.

Hirsuta pilis barbellatis plus minusve patentibus induta. Folia radicalia caespitosa I 2-20 cm. longa, lanceolata vel ovato-lanceolata apice acuta margine integra, lamina $\mathbf{I}-2.5 \mathrm{~cm}$. lata in petiolum brevem basi plus minusve vaginatum sensim attenuata, utrinque viridia, laxe hirsuta. Caulis o. Flores maiusculi pedunculis I-floris simplicibus I2-20 $\mathrm{cm}$. longis laxe hirsutis. Sepala 2, oblonga, extus hirsuta, $3.5 \mathrm{~cm}$. longa, $2 \mathrm{~cm}$. lata. Petala saepissime 8 , lutea, ovato-oblonga, $4 \cdot 5-9 \mathrm{~cm}$. longa, $2-8 \mathrm{~cm}$. lata, utrinque glabra. Stamina $\infty, 3-4$-seriata, filamentis glabris gracilibus discretis. Ovarium e carpellis 4 compositum, dense hirsutum; stylus terminalis glaber $\cdot 8-\mathbf{I} \mathrm{cm}$. longus, sursum plus minusve incrassatus stigmate 4 -lobo terminali lobis radiantibus divaricatis coronatus; placentae parum intrusae; ovula plurima. Capsula matura adhuc ignota.-Kham; in valle fl. Ra-chu, a fontibus fl. Mekong prope, in lat. $29^{\circ} 30^{\prime}$ bor., lon. $97^{\circ} 30^{\prime}$ orient.

The description given is that of a plant presented to Kew by Mr. A. K. Bulley; this plant flowered in the Rock Garden at Kew in May, i 906. The drawing (Pl. XXV) was made by Miss M. Smith from this plant. Another example of the same species flowered at Neston in 1905 . and was figured in 'Flora and Sylva.' These plants were raised from seed received by Bulley from the Imperial Botanic Garden, St. Petersburg. The seeds were sent to St. Petersburg by Captain Koslov from south-eastern Tibet, from the valley of one of the headwaters of the Mekong.

In colour of petals, and in shape and degree of tomentum of leaves, this much resembles $M$. integrifolia. It differs, however, from $M$. integrifolia in all the scapes being simple, radical, and I-flowered, and in having a distinct style with a narrower stigma. The difference in habit between $M$. pseudointegrifolia and $M$. integrifolia is paralleled in the case of $M$. simplicifolia and $M$. grandis.

This species has not ripened seeds, at all events in England. Apparently monocarpic.

15. Meconopsis grandis, Prain. Caulis e rhizomate perennante scapiformis versus apicem fasciculatim foliosus; folia grosse paucidentata; flores in cymas umbelliformes 3 -floras dispositi, nonnunquam floribus $1-2$ axillaribus in parte caulis inferiore adiectis; petala 6-9 fusco-purpurea vel nonnunquam intense coerulea; stylus distinctus; stigma latum. Prain, Journ. As. Soc. Beng., lxiv. 2. 320 (1895) ; Ann. Roy. Bot. Gard. Calcutta, ix. I. 2, t. 2 (1901); Gard. Chron., ser. III, xxxvii. 369, fig. 157 (1905); Flora and Sylva, iii. 82 (1905). 
Himalaya orientalis. Sikkim occidentalis; in pratis alpinis a finibus Nepaliae orientalibus prope, 10-12,000 p.s. m.

This species is like $M$. integrifolia in having a scape-like stem with a cluster of sessile leafy bracts at the apex and generally two flowers there in addition to the terminal one. On the scape below the apical cluster there are usually a few scattered sessile leaves, occasionally in the axils of the highest of these are other flowers. $M$. grandis, however, differs from $M$. integrifolia in having a distinct style, purple not yellow flowers, coarsely toothed not entire leaves, and a sparsely not densely setose capsule.

$M$. grandis is now quite established in a few European alpine gardens, more particularly at Edinburgh, where one old plant had, up to 1906, flowered in at least twelve successive seasons. Usually polycarpic.

16. Meconopsis simplicifolia, Walp. Caulis $\circ$; folia integra vel remote dentata; flores in scapis simplicibus I-floris singuli; petala 6-8, coerulea ; stylus distinctus ; stigma latum. Walp., Rep., i. I10 (1842); Hook. f. \& Thoms., Fl. Ind. 252 (I855); Hook. f., Ill. Him. Pl., t. 8 (I855); Ill. Hortic., iii. II4 (I856); Walp., Ann., iv. I70 (I857); Fl. des Serres, xiii. t. 1324 (1858); Hook. f. \& Thoms., Fl. Brit. Ind., i. II8 (1872); Prain, Journ. As. Soc. Beng., lxiv. 2. 32 I (1895); Flora and Sylva, iii. 84 (1905). Papaver simplicifolium, D. Don, Prodr. Fl. Nepal., I 96 (1825). Stylophorum simplicifolium, Spreng., Syst., iv., cur. post. 203 (1827); G. Don, Gen. Syst., i. I35 (183I); Steud., Nomencl., ed. 2, ii. 650 (I84I).

Himalaya centralis orientalisque. Nepal, Sikkim, Chumbi, Bhutan; in pratis alpinis, $12-16,000$ p.s. m. Tibet AUSTRAlis. Khamba et Phari ; in pratis alpinis $14-15,000$ p. s. m.

In habit and general appearance $M$. simplicifolia agrees with $M$. pseudointegrifolia, as regards fruit it agrees with $M$. grandis. To the latter species it bears somewhat the relationship that the former bears to $M$. integrifolia. The species has long been well known in European alpine gardens. Apparently always monocarpic.

17. Meconopsis quintuplinervia, Regel. Caulis $\circ$; folia integra; flores in scapis simplicibus I-floris singuli, nutantes; petala 4, purpurea; stylus distinctus; stigma latum. Regel, Gartenfl., xxv. 29I, t. 880, figs. b, c, d (1876); Maxim., Fl. Tangut., 34, t. 23, fig. 27 (1889); Flora and Sylva, iii。 84 (1905).

ChINA OCCIDENTALIS. Kansuh; in pratis alpinis, 9,500-I I,000 p. s. m. TiBet BOREALI-ORIENTALIS. Amdo; in pratis alpinis, 9,500-II,000 p.s. m.

This species is nearly allied to $M$. simplicifolia but differs somewhat in foliage, and more considerably in number and colour of petals, also in number of stamens which are here fewer and subbiseriate instead of several-seriate. The capsule 
in this species is more closely covered with setae. By an oversight, the locality for this plant is given in the 'Index Kewensis' as Mandshuria; this error has been copied in 'Flora and Sylva.' No species of Meconopsis occurs in Mandshuria, and its true locality, Kansuh, is correctly given by Regel with the original description of this one.

This species was introduced to European gardens in 1876 but, like $M$. pseudointegrifolia, died down without ripening seeds. Apparently monocarpic.

18. Meconopsis punicea, Maxim. Caulis o; folia integra; flores in scapis simplicibus $\mathrm{I}$-floris singuli, penduli; petala 4, rarissimo in speciminibus cultis 8-9, punicea; stylus o; stigma latissimum. Maxim., Fl. Tangut., 34, t. 23, figs. I 2-2I (I889); Gard. Chron., ser. III, xxxvi. 289, fig. I 30 (I904); Flora and Sylva, iii. 84 (1905).

China occidentalis. Szechuen; in pratis alpinis, I2,000 p.s.m. TIBET BOREALI-ORIENTALIS. In valle Djao-chu.

This species, like $M$. integrifolia, has a large sessile divaricately-lobed stigma, with no disk. It differs in having simple I-flowered scapes with very dark pink flowers, which are pendulous even when fully opened. Usually there are only 4 petals ; the example figured in the 'Gardeners' Chronicle' had, however, 8 to 9. This species is now fairly well established in alpine collections. Apparently monocarpic.

The Grandes constitute a natural group different from the other groups of the section Polychaetia, but in habit resembling the Bellae and the Primulinae in the section Eumeconopsis. From all other groups, except a single species in the group Chelidonifoliae, they stand apart as regards the character of the stigma, the lobes of which are divaricately radiant instead of contiguously decurrent. $M$. grandis is unlike the other species of the group, and is somewhat exceptional in the genus as a whole, in being usually polycarpic; all the others in cultivation have proved monocarpic. All the species appear to flower, as a rule, one year from seed, the leaves dying down during the intervening winter. As a rule also, plants of the monocarpic species that do not flower at the proper time die along with those that do flower; under exceptional circumstances they may survive till another season and flower then.

9 7. Torquatae, Prain. Caules elongati simplices scapiformes; folia subintegra plerumque radicalia; flores numerosi in cymas compactas subspiciformes dispositi; styli distincti vel brevissimi; stigmata oblonga vel clavata lobis decurrentibus contiguis; capsula appresse setosa vertice circa basin styli disco glabro lobato coronata.

19. Meconopsis torquata, Prain. Folia plerumque radicalia margine integra vel subintegra; flores brevissime pedicellati vel sessiles; petala extus parce hirsuta; ovarii discus sinuatus et obtuse angulatus lobis integris ; stylus perbrevis stigmate ovato brevior (Pl. XXIV, Fig. I I).

TIBET AUSTRALIS. In pratis alpinis, $I 1,500$ p. s. $\mathrm{m}$.

Hirsuta pilis patentibus aureo-fuscis basi glanduloso excepto barbellatis induta. Rhizoma an perennans? vaginis numerosis foliorum anni praecedentis obsitum. $\mathrm{B} \mathrm{b}$ 
Folia plurima caespitosa radicalia et subbasalia pauca tamen sparse caulina, ea trientis caulis imi basalibus conformia sed minora, trientis medii parva bracteiformia sed $5^{-6}$ summis floriferis exceptis vacua; radicalia et subbasalia $10-\mathbf{2} \mathbf{2 m}$. longa, spathulata obtusa vel subacuta, margine integra vel remote irregulariterque subsinuata, lamina $\mathrm{I} \cdot 25^{-\mathrm{I}} \cdot 75 \mathrm{~cm}$. lata in petiolum $3^{-4} \mathrm{~cm}$. longum basi plus minusve vaginatum attenuata, supra pallide viridia subtus glaucescentia utrinque sed praesertim subtus petioloque hirsuta; caulina inferiora $4-6 \mathrm{~cm}$. longa, lamina $\cdot 75 \mathrm{~cm}$. lata, petiolo $\cdot 75^{-\mathrm{I}} \cdot 5 \mathrm{~cm}$. longo, superiora bracteiformia irregulariter lobata $\mathrm{I} \cdot 5 \mathrm{~cm}$. long, $.5 \mathrm{~cm}$. lata, sessilia. Caulis ad $40 \mathrm{~cm}$. usque altus, simplex, scapiformis, basi minimo digito crasso cylindricus, sursum praesertim triente summo dense florifero plus minusve sulcatus, prorsus hirsutus. Flores numerosi versus apicem caulis subspicatim aggregati, inferiores tantum bracteati; pedicellis obliquis hirsutis $\cdot 5 \mathrm{~cm}$. longis vel brevioribus nonnunquam obsoletis. Sepala nondum obvia. Petala 4 (an semper?), pallide punicea, oblongo-ovata ad $4 \mathrm{~cm}$. usque longa, $2.5 \mathrm{~cm}$. lata, extus sparse hirsuta intus glabra. Stamina $\infty$, 2-3-seriata, filamentis glabris gracilibus discretis. Ovarium e carpellis 8 compositum, dense setosum ovoideum disco glabro puniceo-purpurascente margine 8-sinuato et obtuse 8-angulato subplicatim explanato et plane astigmatico coronatum; stylus centralis perbrevis ; stigma ovatum integrum lobis contiguis; placentae valde intrusae; ovula plurima. Capsula ovoidea plus minusve angulata, $\mathbf{I} \cdot 35 \mathrm{~cm}$. longa, $\mathbf{I} \mathrm{cm}$. lata, sub margine disci poris 8 dehiscens. Semina plurima, vix matura, ovoidea $2 \mathrm{~mm}$. longa, $.75 \mathrm{~mm}$. lata, testa reticulata.-Tibet: In valle fl. Kyi-chu, I I,500 p.s.m., a Lhasa prope ; in mense Septembri florens, Walton!

Closely allied to the next species, from which it differs only in the shorter pedicels, the much shorter style, the ovate instead of rather narrowly clavate stigma, and the entire in place of toothed disk-margin.

20. Meconopsis discigera, Prain. Folia radicalia margine versus apicem parce grosseque dentata; flores distincte pedicellati, pedicellis capsulam aequantibus; ovarii discus sinuatus et acute angulatus lobis denticulatis; stylus distinctus stigma clavatum aequans (P1. XXIV, Fig. 12).

HimAlayA ORIENTALIS. Sikkim occidentalis ; in pratis alpinis, I II 2,000 p. s. m.

Hirsuta pilis patentibus aureo-fuscis barbellatis induta. Rhizoma an perennans? vaginis foliorum anni praecedentis obsitum. Folia perplurima caespitosa radicalia, I O-I $5 \mathrm{~cm}$. longa, spathulata subacuta, margine versus apicem pauce grosse dentata vel sublobata, lamina $\mathrm{I} \cdot 75^{-2} \mathrm{~cm}$. lata in petiolum $6-8 \mathrm{~cm}$. longum basi plus minusve vaginatum attenuata, supra viridia subtus glaucescentia utrinque petioloque hirsuta; bracteae foliaceae lanceolatae ad $4.5 \mathrm{~cm}$. usque longae, $.5 \mathrm{~cm}$. latae. Caulis ad $30 \mathrm{~cm}$. usque altus, simplex, scapiformis, basi $\cdot 5 \mathrm{~cm}$. crassus cylindricus sursum praesertim dimidio superiore densius florifero plus minusve sulcatus, prorsus hirsutus. Flores racemosi; pedicellis hirsutis $2 \mathrm{~cm}$. longis. Sepala ignota. Petala ignota. Stamina $\infty$, pluri-seriata, filamentis glabris gracilibus discretis. Ovarium e carpellis 6-8 compositum, dense hirsutum, disco glabro margine acute angulato, denticulato, 
explanato, plane astigmatico coronatum; stylus centralis glaber $5 \mathrm{~cm}$. longus; stigma clavatum, plus minusve 2 -lobum, $.6 \mathrm{~cm}$. longum; placentae intrusae; ovula plurima. Capsula oblonga 6-8-angula $\mathrm{I} \cdot 75^{-2} \mathrm{~cm}$. longa, $\cdot 8 \mathrm{~cm}$. lata sub disci margine poris $6-8$ dehiscens. Semina plurima, ovoidea, $2 \mathrm{~mm}$. longa, $\cdot 75 \mathrm{~mm}$. lata, testa reticulata.-Sikkim: Gucha-la, I I-I 2,000 p.s. m., in mense Septembri fructifera, Cave!

Nearly allied to the preceding species, from which it differs in the points already noted. Seedlings of this species have been raised at Kew and at Edinburgh; its establishment in European gardens is therefore to be hoped for.

The Torquatae form a natural and striking group. Their habit recalls that of the Aculeatae of the section Eumeconopsis, with however more numerous and more closely set flowers, so that, especially in $M$. torquata, the cymes are spicate rather than racemose. As compared with the other groups of the section Polychaetia, in which the hairs are of the same character (see Pl. XXV; Fig. 3), the Torquatae agree with the Grandes as regards foliage, with the Robustae in having numerous flowers. In the Robustae, however, the stems are tall and stately, are leafy throughout, and bear their flowers in loose racemose or paniculate, not in congested or subspicate cymes, As in the case of the group Bellae, the very stout rhizomes and the plentiful remains of old leaves suggest the possibility that the Torquatae may be perennials; there is, however, as yet no direct proof that they are other than monocarpic, and it may be that the explanation is merely that the species of this group do not flower till several years from seed have elapsed.

8. Robustae, Prain, Journ. As. Soc. Beng., 1xiv. 2. $3^{1} 5$ (1895). Caules magnopere evoluti elati plerumque copiose ramosi; folia grosse dentata vel varie lobata caulina numerosa sparsa ; flores numerosi in cymas laxas racemiformes paniculatasve dispositi, petalis 4 ; styli distincti ; stigmata clavata lobis decurrentibus contiguis ; capsula nunc appresse nunc patenter setosa in stylum sensim attenuata.-Herbae monocarpicae.

21. Meconopsis superba, King. Folia radicalia sinuato-lobata caulina grosse dentata laxe pilis barbellatis simulac dense indumento stellato induta; sepala laxe strigosa et dense stellato-tomentosa; flores albi in cymas racemiformes dispositi; capsula valvis 8 -I I appresse setosa et dense stellato-tomentosa; stylus brevis basi manifeste incrassatus. King ex Prain in Journ. As. Soc. Beng., lxiv. 2. 317 (1895); Ann. Roy. Bot. Gard. Calcutta, ix. I. 4, t. 5 (I901). M. nepalensis, Flora and Sylva, iii. 84 (1905) partim et quoad exempla albiflora prolata.

Himalaya ORIENTALIS. Bhutan; in pratis alpinis, IO-I I,000 p.s. m.

Very nearly related to $M$. paniculala and apparently only a representative of that species in a locality somewhat further to the east. The habit and foliage are exactly as in $M$. paniculata, but the stems appear to be taller and stouter even than in that species, and the flowers, which are larger, are white. Whether this has been introduced to European gardens is not clear; it is reported (Flora and Sylva, iii. 84) that a Meconopsis bearing large bell-shaped flowers of an ivory-white

$\mathrm{B}$ b 2 
has been met with in cultivation. The plant is treated, in the passage referred to, as a form of $M$. nepalensis (i. e. of the plant here termed $M$. paniculata, not of the true red-flowered $M$. napaulensis), but no reference is given to the collection in which this white-flowered plant has existed, and no definite authority for the statement is quoted. In all probability $M$. superba, like the other members of the group Robustae, is monocarpic.

22. Meconopsis paniculata, Prain. Folia radicalia sinuato-lobata raro pinnatifida, caulina grosse dentata vel interdum parum lobata laxe pilis barbellatis simulac dense indumento stellato induta; sepala laxe strigosa et dense stellato-tomentosa; flores lutei, in cymas racemiformes dispositi; capsula valvis 8-1 I appresse setosa et dense stellato-tomentosa ; stylus brevis basi manifeste incrassatus. Prain, Journ. As. Soc. Beng., lxiv. 2. 3 I6 (I 895). M. napaulensis, Walp., Rep., i. I IO (I842) non DC. $M$. Wallichii, Hook. f. \& Thoms., Fl. Ind, 254 in parte (I855); Walp., Ann., iv. I7I in parte (1857) ; Hook. f. \& Thoms., Fl. Brit. Ind., i. II9 in parte (1872)-quoad exemplum sub Wall. Cat., 8I23/b prolatum, non Hook. Papaver paniculatum, D. Don, Prodr. Fl. Nepal., I97 (1825)-quoad descriptionem sed syn. Meconopsis napaulensis excl. Stylophorum paniculatum, G. Don, Gen. Syst., i. I 35 in parte (I83 I) et quoad exempla floribus luteis prolata tantum. S. nepalense, Steud., Nomencl., ed. 2, 650 in parte (I84I). Polychaetia paniculata, Wall. ex Prain, Journ. As. Soc. Beng., 1xiv. 2. 3 I6 (I895).

Himalaya centralis orientalisque. Nepal, Sikkim, et Bhutan; in pratis alpinis, IO-II,OOJ p.s. m.

Hardly separable even as a variety from the next form, owing to the existence of numerous intermediates.

Var. elata, Prain. Flores in cymas laxe paniculatas dispositi, caeterum typi. Prain, Journ. As. Soc. Beng., lxiv. 2. 316 (1895). M. nipalensis, Hook. f. \& Thoms., F1. Ind., 253 (I855) ; Hook. f., Ill. Him. P1., t. 9 (1855); Walp., Ann., iv. I7I (I857) ; Hook. f. \& Thoms., Fl. Brit. Ind., i. I 8 (1872) nec $M$. napaulensis, DC. $M$. nepalensis, Lem., Ill. Hortic., iii. 95 (1856); Flora and Sylva, iii. 83 (I905), nec $M$. napaulensis, DC. $M$. Wollastonii, Regel, Gartenfl., xxv. 29 I (I876) nomen tantum.

Himalaya Centralis ORIentalisque. Nepal et Sikkim; in pratis alpinis, $10-I I, 000$ p. s. m.

This form is treated here as a variety, rather as a matter of convenience than of necessity. The two are easily distinguished in their extreme states; they, however, pass insensibly into each other. By keeping them apart it is more easy to disentangle the confused synonymy that has resulted from the erroneous reduction by Don, to one of them, of De Candolle's very different $M$. napaulensis.

The species is familiar in European alpine gardens. Apparently always monocarpic. 
23. Meconopsis robusta, Hook. f. \& Thoms. Folia radicalia pinnatipartita caulina pinnatifida glaucescentia pilis barbellatis sparse strigosa; sepala laxe strigosa; flores lutei in cymas racemiformes paniculatasve dispositi ; capsula valvis 8-II laxe patenter setosa; stylus brevis basi manifeste incrassatus. Hook. f. \& Thoms., Fl. Ind., 253 (1855); Walp., Ann., iv. 17 I (1857); Prain, Journ. As. Soc. Beng., lxiv. 2. 3I5 (1857); Strachey, Pl. Kumaon, Io (I906). M. nipalensis, Hook. f., Bot. Mag., t. 5585 ( ( 866 ), nec $M$. napaulensis, DC. M. robusta, Hook. f. \& Thoms., Fl. Brit. Ind., i. I 18 (1872), pro parte maxima sed exemplum nepalense prolatum excludend. M. paniculata, Flora and Sylva, iii. 84 (1905) nec Prain. Argemone mexicana, Wall. in Cat. Lith., 8126 E (I830) nec Linn.

Himalaya occidentalis. Garhwal et Kumaon; in pratis alpinis, 8-I 2,000 p. S. m.

$M$. robusta is nearly allied to $M$. paniculata and is the representative of that species in the western Himalaya. It is readily distinguished from $M$. paniculata and $M$. superba by its more deeply lobed leaves and by the absence of stellate pubescence; with both it agrees as regards the shape of the capsule and style. As regards foliage, though not as regards indumentum, it agrees with $M$ napaulensis and $M$. Wallichii, rather than with $M$. paniculata; from these two, however, it differs markedly in respect to the shape of the capsule and style.

Occasionally to be met with in European collections, this appears to be as a rule confused with $M$. paniculata. The latest instance of this confusion (Flora and Sylva, iii. 84) corrects itself. The remark that the foliage of the plant referred to is 'much cut' shows that the author cannot have had the true $M$. paniculata in view. Besides, in the article referred to, the true $M$. paniculata is already accounted for under the erroneous name $M$. nepalensis. Apparently always monocarpic.

24. Meconopsis napaulensis, DC. Folia radicalia pinnatipartita caulina pinnatifida laxe pilis barbellatis simulac dense indumento stellato induta; sepala laxe strigosa et dense stellato-tomentosa; flores fuscopurpurei in cymas paniculatas dispositi; capsula valvis $5^{-7}$ patenter vel subreflexe setosa; stylus elongatus subcylindricus. DC. Prodr., i. I2I (1824); Prain, Journ. As. Soc. Beng., lxiv. 2. 3I7 (1895). M. robusta, Hook. f. \& Thoms., Fl. Brit. Ind., i. 118 ( 1872 ) pro parte minima et quoad exemplum nepalense (Wall. Cat., 8I2I) prolatum, nec $M$. robusta, Hook. f. \& Thoms. in Fl. Ind. $M$. Wallichii, var. rubrofusca, Hook. f., Bot. Mag., t. 6760 (1884). Stylophorum nepalense, Spreng., Syst., iv., cur. post. 203 (1827) ; Steud., Nomencl., ed. 2, ii. 650 (1841) partim. S. paniculatum, G. Don, Gen. Syst., i. I35 (I 83 I), partim et quoad exempla floribus rubris prolata.

Himalaya CEnTRAlis orientalisque. Nepal et Sikkim occidentalis; in pratis alpinis, $10-12,000$ p.s. $m$.

This species resembles $M$. robusta in foliage, and specimens corresponding to the original type were in 1872 referred by Hooker and Thomson to that species, 
It resembles still more closely $M$. Wallichii, with which it agrees not only in shape of leaves but in shape of capsule and style, and living examples were in I 884 treated by Sir J. D. Hooker as the bas:s of his $M$. Wallichii, var. rubrofusca. It has recently been stated (Flora and Sylva, iii. 85) that a large proportion of seedlings from homesaved seed of $M$. Wallichii, which has blue flowers, often turn out as shades of dirty purple and brown. If this observation were confirmed-it is not, however, stated on what or on whose authority it is made-it would appear as if $M$. Wallichii were not even varietally separable from $M$. napaulensis. At Kew, however, the writer is informed by Mr. Irving, the occurrence reported only happens when seed is taken from plants of $M$. Wallichii which have been growing alongside of plants of $M$. napaulensis; otherwise both plants come true to seed. The two are undoubtedly representative species, but $M$. napaulensis appears to cease in western Sikkim where $M$. Wallichii begins.

M. napaulensis appears to have been known in European gardens before $\mathbf{I} 83 \mathbf{I}$. At all events, G. Don was aware that there were two Nepalese plants, one with yellow, the other with red flowers, so like each other in general appearance that he felt constrained to treat them as forms of a single species, Siylophorum paniculatum. Seeds of both may quite well have reached Europe from Nepal with the other seeds that we know from various sources to have been dispatched from that country by Wallich. When the nature of Wallich's herbarium specimens of the two plants is considered, it is not conceivable that G. Don could have learned, certainly D. Don six years previously did not know, that there were both yellow-flowered and redflowered paniculate poppies in Nepal, unless living examples had somewhere and somehow come under his notice. There is, however, no definite record of the flowering of $M$. napaulensis in Europe till $\mathbf{1} 88_{4}$, when a plant, raised from seed sent from Sikkim by Sir G. King, flowered with the late Mr. Wilson at Weybridge. Since that date $M$. napaulensis has become well established in English gardens. Apparently always monocarpic.

25. Meconopsis Wallichii, Hook. Folia radicalia pinnatipartita caulina pinnatifida laxe pilis barbellatis simulac dense indumento stellato induta; sepala dense stellato-tomentosa rarius etiam laxe strigosa; flores coerulei in cymas paniculatas dispositi; capsula valvis 5-7 primum appresse deinde patenter setosa; stylus elongatus subcylindricus (Pl. XXIV, Fig. 6). Hook., Bot. Mag., t. 4668 (1852) ; Jard. Fleur., iii. t. 3I 5 (1853); Belg. Hortic., iv. t. I8 (I8.54); Fl. des Serres, viii. t. 735 (I855); Hook. f. \& Thoms., Fl. Ind., 254 (I855); Walp., Ann., iv. I7I (I857); Hook. f. \& Thoms., Fl. Brit. Ind., i. I I9 (I872) omnes partim et quoad exemplum sikkimense floribus coeruleis prolatum sed exemplo nepalensi (Wall. Cat., $8 \mathrm{I} 23 / \mathrm{b}=$ Polychaetia paniculata, Wall.), cui flores lutei, excluso; Dym. Ward. \& Hoop., Pharmacogr. Ind., i. II 2 (I889); Prain, Journ. As. Soc. Beng., lxiv. 2. 318 (1895); Flora and Sylva, iii. 84 c. ic. (1905).

Himalaya orientalis. Sikkim, Chumbi et Bhutan; in pratis alpinis, I0-12,000 p. s.m. ChInA OCCIDENTALIS. Szechuen; in pratis alpinis, I2,000 p. s. m. 
This species in habit and general appearance agrees almost as closely with $M$. napaulensis as does $M$. Oliveriana with $M$. chelidonifolia. In the present instance, indeed, the parallelism extends to the ovary and the fruit, which are, when quite ripe, barely distinguishable. There is a slight difference in tomentum; there are fewer long barbellate hairs on the leaves of $M$. Wallichii than on those of $M$. napaulensis, and usually, though not always, the sepals of $M$. Wallichii have only a close-felted stellate tomentum, the long barbellate hairs being absent. This, however, is neither a sufficiently distinct nor a sufficiently constant character to warrant the separation of the two, and the most definite distinction lies in the colour of the flowers, blue in $M$. Wallichii, red in $M$. napaulensis. Though it is reported that, when the two are grown side by side, seed produced by plants of $M$. Wallichii may result in plants with flowers like those of $M$. napaulensis, it is remarkable that intermediates have not been recorded. It is further to be observed that $M$. Wallichii has never been collected in central or eastern Nepal where M. napaulensis appears to be common, and that, on the other hand, $M$. napaulensis does not extend eastward from western Sikkim into the area in which $M$. Wallichii is a characteristic species. In horticulture the two must always be distinguished; it seems, therefore, preferable to continue to treat them as specifically separable.

This species was originally introduced to European gardens by Sir Joseph Hooker more than half a century ago. It is now perhaps the most familiar and most thoroughly established of all the Asiatic species of Meconopsis. Apparently always monocarpic.

The Robustae form a distinct and natural group; all of the species have tall leafy stems rarely less than $4-5$ feet, often as much as 8-io feet high, with numerous flowers disposed in laxly raceme-like or paniculate cymes. The flowers are 'papaveroid,' no tendency to an increased number of petals has ever been observed in the group; the capsules, styles and stigmas are typical of the genus. The group stands almost alone in the fact that as a rule they do not flower till the second year from seed, and that during the two intervening winters the rosette of leaves persists. Apparently all die after flowering.

The synonymy, as will be seen from the citations under the various species, has been much confused. This is perhaps hardly to be wondered at when the distribution within the group of its characteristic features is taken into consideration. Disregarding for the moment the colour of the petals, we find that while all are beset with barbellate hairs four of the Robustae have also a close-felted stellate tomentum. By this character therefore we obtain two sub-groups consisting of (I) $M$. robusta itself without this felted tomentum, and (2) $M$. superba, $M$. paniculata, $M$. napaulensis and $M$. Wallichii with it. If, however, we neglect the tomentum and consider the character of the ovary and capsule we have again two sub-groups; (I) including $M$. robusta, $M$. superba, and $M$. paniculata, with eight or more valves, with a short style thickened considerably at the base and with persistently adpressed setae; and (2) including $M$. napaulensis and $M$. Wallichii with seven or fewer valves, with a longer and more slender style, and with ultimately spreading setae. If, on the other hand, we consider the character of the foliage apart from the tomentum, we find again two sub-groups; (I) including $M$. superba and $M$. paniculata, with the leaves slightly 
lobed or only toothed; (2) including $M$. robusta, $M$. napaulensis, and $M$. Wallichii, with much divided leaves. Of these three alternative groupings, that which is based on the differences as regards gynoecium and fruit is doubtless the most natural; it has the further advantage of according best with the differences as regards colour of petals, for the forms with 8-II-valved ovaries and persistently adpressed setae have the flowers yellow or ivory-white, the forms with $5-7$-valved ovaries and ultimately spreading setae have the petals blue or red. If, therefore, reduction be insisted upon, we may with some justification recognize but two species, viz.:- I, $M$. paniculata, including, as a variety, $M$. superba, and, as a subspecies, $M$. robusta; 2, M. napaulensis, including, as a variety, $M$. Wallichii. The confusion indicated by the synonymy has not, however, been altogether the result of a difficulty in deciding which of these mutually incompatible differential characters may be the more important. It has largely had a purely bibliographical origin and has resulted from the reduction by D. Don (Prodr. Flor. Nepal., 197) of De Candolle's Meconopsis napaulensis to his own Papaver paniculatum, which is Meconopsis paniculata. Why Don made this suggestion is not at all clear; his account of $M$. paniculata is by no means unsatisfactory; even if it had been so, an accident has made the misidentification of Don's species impossible. His description does not tally with De Candolle's brief diagnosis of $M$. napaulensis, and an examination of De Candolle's original specimen shows that the two are different, both as regards foliage and as regards fruit. Don's erroneous reduction has, however, been so generally followed, that in horticulture it has become usual to associate De Candolle's name for the red-flowered member of this group with sometimes one, sometimes another of the yellow-flowered ones. The writer attempted in 1895 (Journ. As. Soc. Beng., lxiv. 2. 3I 7, 318) to unravel this somewhat tangled skein, and tried to make it clear that what has so often been taken for $M$. napaulensis is really $M$. paniculata. A reference to one of the most recent resumés of our information with regard to this genus Flora and Sylva. iii. 8I-84) shows, however, that the old confusion is still perpetuated, and that the only result of the writer's previous note on the subject has been to originate a new confusion; the name 'M. nepalensis,' which belongs to a red-flowered species, is still associated with one of the yellow-flowered ones, and the name 'M. paniculata,' which belongs to this yellow-flowered one, has been transferred to a second yellow-flowered species which has already been properly named and accurately described by Hooker and Thomson as $M$. robusta. Under the circumstances it seems advisable to state the facts once more as explicitly as possible.

The specimen on which De Candolle based his diagnosis of $M$. napaulensis was collected by Wallich in Nepal in $\mathbf{I} 8 \mathbf{I} 9$, and was sent by him to Geneva prior to $\mathbf{1} 824$. De Candolle's diagnosis, though brief, is, when taken in conjunction with collateral evidence, adequate for the recognition of the plant.

It has been shown under $M$. aculeata that Jacquemont believed the plant which Royle subsequently so named to be De Candolle's $M$. napaulensis, that Honigberger also held this view, and that at a later date Falconer was of the same opinion. Possibly these botanists were led to this conclusion because De Candolle has described $M$. napaulensis as being 'capsulis valde echinatis,' a phrase appropriate to the prickly capsules of $M$. aculeata. However, De Candolle's references to the style 
and to the indumentum of $M$. napaulensis prove that his species cannot be Royle's M. aculeata. Moreover, when it is recollected that De Candolle uses the phrase 'capsulis echinatis' with regard to his Meconopsis petiolata, which is Chelidonium diphyllum, Michx., it will be realized that he does not necessarily imply that the capsules of $M$. napaulensis are prickly; and an examination of the actual specimen which De Candolle had before him shows that its capsules are not prickly and that it is not the plant named $M$. aculeata by Royle.

D. Don, a year after De Candolle's diagnosis was published, described two Nepalese species of Meconopsis from specimens sent by Wallich to Lambert at the same time that $M$. napaulensis was sent by Wallich to De Candolle. One of these two had been named Polychaetia paniculata by Wallich before the specimens left India. For some reason Wallich did not send examples of either of these two species to De Candolle; on the other hand, Wallich evidently sent no example of $M$. napaulensis to Lambert. Don did not admit that Meconopsis was generically distinct from Papaver; it is therefore not surprising that he could not follow Wallich in considering Polychaetia separable from Meconopsis. But Don did take up Wallich's manuscript specific name paniculata - a circumstance so far fortunate, since it enables us, knowing as we do the plant to which Wallich gave the name Polychaetia paniculata, to state with certainty what the plant described by Don as Papaver paniculatum really is.

When in $183^{\circ}$ Wallich distributed, independently of his communications at an earlier date to De Candolle and to Lambert, specimens of all the species of Meconopsis in the Calcutta Herbarium, he issued them under the following numbers:- 8 I $2 \mathrm{I}$,

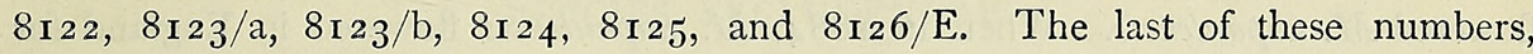
collected in Kumaon, is $M$. robusta, Hook. f. and Thoms.; it is evident that its issue under the name Argemone mexicana was a mere accident. Of the others 81 25 , from Nepal, is $M$. simplicifolia, Walp., not previously sent to De Candolle, though it was previously sent to Lambert, in whose herbarium Don named and described it as Papaver simplicifolium; $8 \mathbf{1} 24$, collected in Kumaon by Blinkworth, but neither sent to De Candolle nor to Lambert, is M.robusta, Hook. f. and Thoms. The plant from Nepal to which Wallich in India attached the name Polychaetia paniculata, was issued in 1830 under the Catalogue number $8 \mathbf{I}_{2} 3 / \mathrm{b}$; this plant, though not sent to De Candolle before 1824 , was previously communicated under this manuscript name to Lambert, and was consequently described by Don as Papaver paniculatum. As regards the locality of 8123 /a Wallich seems to have been in doubt; the entry against it in the Catalogue is 'Kumaon?'. There is, however, no doubt with regard to its identity; it is not $M$. robusta, Hook. f. and Thoms., the only species of this group that, so far as we know, occurs in Kumaon; it is a form of, and is hardly varietally separable from, $M$. paniculata. The next number, 8 I 22 , from Kumaon, is $M$. aculeata, Royle, and calls for no remark. The only other number, $8 \mathrm{I} 2 \mathrm{I}$, which came from Nepal, is found on comparing it with the specimen in the Prodromus Herbarium at Geneva to be the plant which Wallich had previously sent to Geneva at the time that he sent $M$. simplicifolia and $M$. paniculata to Lambert, and is therefore the plant that De Candolle described as $M$. napaulensis.

The reduction by $D$. Don of this species, specimens of which he clearly had never seen, to his own very distinct $P$ apaver paniculatum has already been commented 
on. How little real ground there was for the reduction may be gathered from the treatment accorded to the two plants by Hooker and Thomson. These authors, it is true, have nominally accepted Don's reduction of M.napaulensis to Papaver paniculatum. But they have pointed out (Flor. Ind., 253) that De Candolle's description of $M$. napaulensis tallies better with that of their own species $M$. robusta than it does with that of Don's Papaver paniculatum, which is their $M$. nipalensis. In $\mathbf{1} 855$, when this remark was published, Hooker and Thomson did not account for Wallich's $8 \mathrm{I} 2 \mathrm{I}$, which we know now is the true $M$. napaulensis; when, however, in 1872 , the same authors (Flor. Brit. Ind, i. I 8 ) did deal with the actual specimens of whatthough they did not yet know this fact-is $M$. napaulensis, it is significant that it was to their own $M$. robusta, not to their own $M$. nipalensis, that they referred the plant. Apart, however, from the fact that the indumentum of Wallich's 8I26/E and 8I24, which really belong to $M$. robusta, Hook. f. and Thoms., is not the same as the indumentum of Wallich's 8 I 2 I, which really belongs to $M$. napaulensis DC., and that though the foliage of the two is similarly divided the capsules and styles are different, we now know that $M$. robusta has yellow flowers like those of $M$. paniculata, and that the flowers of $M$. napaulensis are red. The position of $M$. napaulensis, as a species distinct from either of the yellow-flowered members of the group Robustae, is now established beyond dispute, and the question at issue is no longer whether $M$. napaulensis is, or is not, different from $M$. paniculata or $M$. robusta, but whether the blue-flowered Sikkim Poppy, $M$. Wallichii, so familiar in alpine gardens, is really specifically distinct from the much older, though less perfectly understood redflowered $M$. napaulensis. When, in $\mathbf{1 8 8 4}, M$. napaulensis flowered in England for the first time, as to which we have a definite record, Sir J. D. Hooker had no hesitation in treating it as a variety of $M$. Wallichii. That the two are closely allied is certain, and that they are representatives the one of the other in immediately adjacent areas is true. The form that the necessary reductions will take, if they must be effected, has been indicated. From the cultural point of view, however, these reductions would hardly be beneficial; the writer therefore prefers to leave these various forms as they are.

9. Chelidonifoliae, Prain, Journ. As. Soc. Beng., 1xiv. 2. 3I3 (I895) $M$. cambrica excludenda. Inermes; perennantes; caules elongati ramosi foliosi; folia pinnatifida sparse hirsuta; flores lutei petalis 4 ; stylus nunc stigmate globoso-clavato distinctus, nunc stigmate depresso-dilatato subobsoletus ; capsula glabra sensim in stylum attenuata vel subito in stigmatis plicaturas extensa.

26. Meconopsis chelidonifolia, Bur. \& Franch. Rhizoma villosum; folia ovato-oblonga segmentis ovatis lobis obtusis vel subobtusis, caulibusque sparse strigosa; sepala glabra; capsula ovata stylo distincto. Bur. \& Franch., Journ. de Bot., v. I9 (I89I); Flora and Sylva, iii. 82 (I905).

China occidentalis. Szechuen occidentalis ; in dumetis et umbrosis, I 3,000 p. s. m.

In every character except the fruit this plant is quite like $M$. Oliveriana. In this species the fruit is that of a typical Meconopsis, only half as long as that of 
M. Oliveriana, and with a distinct style. Not yet introduced into European gardens. Evidently perennial.

27. Meconopsis Oliveriana, Franch. \& Prain. Rhizoma villosum; folia ovato-oblonga segmentis ovatis lobis obtusis vel subobtusis, caulibusque sparse strigosa; sepala glabra; capsula anguste cylindrica stylo perbrevi. Franch. \& Prain, Journ. As. Soc. Beng., lxiv. 2. 312 (1895).

CHINA CENTRALIS et OCCIDENTALIS. Hupeh; in dumetis et umbrosis. Szechuen orientalis ; in dumetis I 2,000 p. s. m.

This species agrees in every character with $M$. chelidonifolia except as regards the fruit, which is in this species very like that of Cathcartia villosa, but only opens by short valves at apex, not all the way down as in a Cathcartia. Not yet introduced into European Gardens. Evidently perennial.

The Chelidonifoliae include only two species, which are so much alike that they can only be distinguished by their ripe capsules. These, however, are so dissimilar that while one has a style and stigma such as is characteristic of the majority of the species in the genus, the other has a sessile stigma exactly like that of $M$. punicea and $M$. integrifolia, or like that of Cathcartia villosa. In habit the two species are unlike any of the groups of Meconopsis except the Cambricae; in this respect they agree with Cathcartia § Eucathcartia. The capsules, however, open by the short apical valves characteristic of Meconopsis.

\section{SPECIES EXCLUDENDAE.}

Meconopsis Betonicifolia, Franch., Pl. Delavay., 42, t. I2 (I889). = Cathcartia betonicifolia, Prain.

This species has been accurately described by Franchet loc. cit., and the question as to whether the generic position assigned to the plant by Franchet, or that suggested by the writer, be the correct one turns on the nature of the ripe fruit, which as yet is unknown.

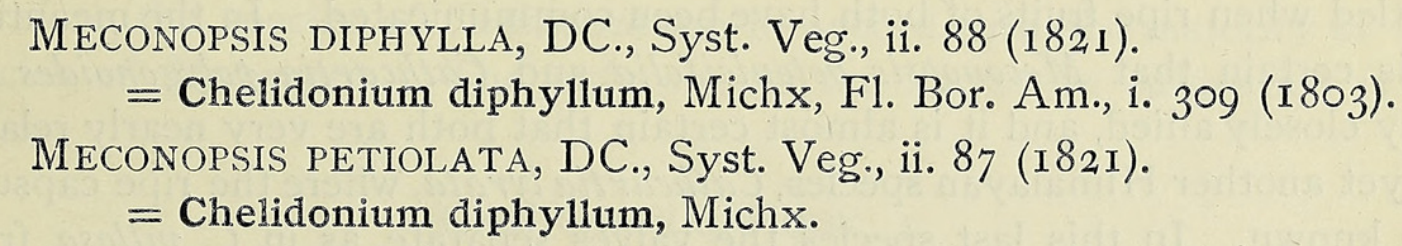

\section{CATHCARTIA.}

The genus Cathcartia was founded in $185 \mathrm{I}$ by Sir J. D. Hooker (Bot. Mag., t. 4596) to accommodate a yellow-flowered Himalayan Poppy collected by himself in Alpine Sikkim. The name perpetuates the memory of J. W. F. Cathcart, a member of the Indian Civil Service who, with the help of a native artist, prepared an important series of drawings of Siklim plants. The validity of the genus has never been questioned, but its history during the past thirty years has been complicated by the reference to it of species that do not really belong. The first addition was suggested by 
Maximowicz in 1876 when he described a Chinese Poppy as Cathcartia integrifolia (Mel. Biol., ix. 7I3). So far as the colour of the petals and the shape of the stigma are concerned, this plant, of which Maximowicz had not seen ripe fruits, is very like Hooker's original C. villosa. Subsequently further material with ripe capsules reached Paris, and in I886 Franchet was able to show (Bull. Soc. Bot. Fr., xxxiii. 389 ) that Maximowicz's C. integrifolia is a genuine Meconopsis, the capsules opening as in other members of that genus by small apical chinks, and not, as in $C$. villosa, by valves that separate from the placental ribs to the base of the fruit. But in the place and at the time that Franchet made this rectification he himself published as Cathcartiae two species, C. lancifolia and C. Delavayi, which have proved to be species of Meconopsis. On the other hand, in 1889 Franchet published (P1. Delavay., 42, t. I2), as Meconopsis betonicifolia, a species which the writer suspects may be a Cathcartia.

The writer was able in 1894 to study at Paris the abundant Chinese material of the natural family Papaveraceae in the Museum at the Jardin des Plantes, and owed much to the kindness with which Franchet put at his disposal the minute and extraordinary knowledge of the flora of southwestern China which that generous and erudite botanist possessed. Franchet then pointed out that his original view as to the position of C. lancifolia and C. Delavayi required modification, and honoured the writer by permitting him to publish in I 895 (Journ. As. Soc. Beng., lxiv. 2. $3^{\text {II }}$ ) the corrected determinations. As regards Meconopsis (or Cathcartia) betonicifolia, Franchet did not, however, think it advisable to modify his original view. This fact should be kept in mind by those who may hereafter have occasion to examine the plant in question. The actual position of this Chinese species, and of another from the eastern Himalaya which the writer has treated as a Cathcartia, C. polygonoides, can only be definitely settled when ripe fruits of both have been communicated. In the meantime it is certain that Meconopsis betonicifolia and Cathcartia polygonoides are very closely allied, and it is almost certain that both are very nearly related to yet another Himalayan species, Cathcartia lyrata, where the ripe capsules are known. In this last species the valves separate, as in C. villosa, from apex to base. For this reason the writer prefers, so long as the question as regards the other two is an open one, to place them beside C. lyrata and enumerate them in the genus Cathcartia rather than in the genus Meconopsis.

The genus Cathcartia is closely allied to the genus Meconopsis; the differential characters originally relied on were mainly the practical absence of a style in Cathcartia and the complete, in place of partial, separation of the valves from the placental ribs. But the character derived from the absence of a style is no longer differential, because there are at least three species of Meconopsis-M. Oliveriand in the group Cheiddonifoliae, with 
$M$. integrifolia and $M$. punicea in the group Grandes-where the depressed radiant stigma is situated, as in Cathcartia villosa, immediately on the vertex of the capsule. The introduction into Cathcartia of stylate species, if their valves do separate to the base, is no greater violation of its natural limits than is the retention in Meconopsis of the three non-stylate species mentioned.

The indumentum of Cathcartia villosa consists of barbellate hairs like those in the species of Meconopsis $\S$ Polychaetia; the hairs on the three stylate species are, on the other hand, simple, as in Meconopsis $§$ Eumeconopsis. This character, in Meconopsis, appears to be of more consequence, from the taxonomic point of view, than the presence or absence of a style; it may be accepted as of equal importance in Cathcartia. Small as are the two groups which this character gives us, it seems therefore advisable to treat them as distinct sections. It has, indeed, to be pointed out that the only species of the three stylate Cathcartias with simple hairs of which we know the ripe fruit was considered by Sir G. King to deserve generic rank.

In habit the species of Cathcartia show considerable uniformity. All of them fall into the first of the three habit-series distinguishable within Meconopsis; they have slender non-scapose leafy stems with perennial rootstocks and few-flowered cymes, or even solitary flowers, terminating these leafy stems.

The distribution of the various species is as local as in the case of Meconopsis; C. villosa is known only from Sikkim and East Nepal; C. lyrata only from Sikkim; C. polygonoides only from Chumbi; and C. betonicifolia only from Yunnan.

All four species are truly alpine; none of them occur below I0,000 feet or go beyond 14,000 feet above sea-level; all are confined to the zone between $25^{\circ}$ and $30^{\circ}$ lat. N. As regards every feature of their distribution, therefore, the species of Cathcartia are in accord with the majority of the species of Meconopsis. The only one so far known in cultivation is $C$. villosa.

\section{Cathcartia, Hook. F.}

Bot. Mag., t. 4596 (185I); Benth. \& Hook. f., Gen. Pl., i. 52 (I862); Baill., Hist. des Plantes, iii. I40 (1872); Prantl \& Kundig, Nat. Pflanzenfam., iii. 2. I4I (I889).

Sepala 2. Petala 4. Stamina $\infty$. Ovarii placentae $3^{-6}$ nerviformes vel plus minusve intrusae; stylus distinctus vel obsoletus; stigmatis clavati vel depresso-dilatati lobi decurrentes subcontigui vel radiantes divaricati placentis oppositi. Capsula oblonga vel anguste cylindracea vertice in stylum sensim vel sub stigmate subsessili abruptius attenuata, valvis ab apice ad basin usque placentas cum stigmate styloque persistentes nudantibus dehiscens,-- Semina scrobiculata vel laevia raphe cristata vel nuda.--Herbae 
perennantes succo flavo. Folia lobata crenatave. Flores longe pedunculati in cymas paucifloras racemiformes vel singuli caulem terminantes dispositi, speciosi, alabastris nutantibus.

Species 4, quarum 3 in Himalaya orientali, I in China austro-occidentali crescunt.

Genus in sectiones naturales 2 commode dividitur; scil. :-

$\S$ Eucathcartia. Pilis setisve barbellatis densius indutae; flores lutei; stylus subnullus; stigmatis lobi radiantes divaricati.

$\S \S$ Cumminsia. Pilis simplicibus sparse obsitae; flores coerulei vel purpurascentes; stylus distinctus; stigmatis lobi decurrentes contigui.

\section{Clavis SPECIERUm.}

Flores lutei, maiusculi ; stamina $3^{2}$; stigma depresso-dilatatum lobis radiantibus divaricatis; folia dense villosa

I. villosa.

Flores purpurei vel coerulei; stigma clavatum lobis decurrentibus contiguis; folia sparse hirsuta :-

Folia ovato-lanceolata ; petala margine integra :-

Flores majusculi ; petala rotundata, obtusa ; stamina 64

2. betonicifolia.

Flores minores; petala ovato-lanceolata, acuta; stamina i $6 \quad 3$. polygonoides

Folia integra hastata, vel lobata lyrato-pinnatifida ; flores minores ; petala ovatolanceolata obtusa apice subfimbriata; stamina i 6

4. Iyrata.

$\S \mathrm{I}$. Eucathcartia. Herbae dense pilis setisve barbellatis villosae; folia radicalia plurima cordata lobata ; flores lutei ; capsula anguste cylindracea; stylus subnullus; stigma depresso-dilatatum lobis divaricatis radiantibus.

1. Cathcartia villosa, Hook. f. Folia molliter villosa, radicalia plurima, cordata $3-5$-lobata lobis plus minusve incisis; flores maiusculi lutei in cymas racemiformes paucifloras caulem terminantes dispositi, pedicellis axillaribus ; stamina 32 ; capsula anguste cylindracea; stylus subnullus; stigma latum depresso-dilatatum; semina scrobiculata raphe cristata. Hook. f., Bot. Mag., t. 4596 (I85I) ; Fl. des Serres, vii. t. 686 (1851) ; Lem., Jard. Fleur., ii. t. I67 (I8.52); Hook. f. \& Thoms., Flor. Ind., 254 (I855); Hook. f., Ill. Him. Pl., frontisp. (1855); Walp., Ann., iv. I75 (1857); Hook. f. \& Thoms., Flor. Brit. Ind., i. I I 9 (I872) ; Prain, Journ. As. Soc. Beng., lxiv. 2. 325 (1 895).

Himalaya orientalis. Nepal orientalis et Sikkim; in pratis alpinis, IO-I 2,000 p. s. m.

Habit of Meconopsis Oliveriana and $M$. chelidonifolia, but more hairy, with more numerous radical leaves, much larger flowers, and a capsule in shape like that of Meconopsis Oliveriana but larger, and with the valves separating to the base.

$\S$ II. Cumminsia. Herbae sparse pilis simplicibus hirsutae; folia radicalia saepissime pauca margine crenata vel lyrata lobata ; flores purpurei 
vel coerulei; capsula ovata vel anguste cylindracea; stylus distinctus; stigma clavatum lobis decurrentibus contiguis. Cumminsia, King MSS. (gen.) in Herb. Calcutta et in Herb. Kew.

2. Cathcartia betonicifolia, Prain. Folia glabrescentia, radicalia numerosa, ovato-oblonga obtusa inciso-crenata ; flores maiusculi purpurascentes in cymas racemiformes paucifloras caulem terminantes dispositi, pedicellis axillaribus; stamina 64 ; capsula (haud matura) oblongo-ovata in stylum distinctum sensim attenuata; stigma clavatum. Meconopsis betonicifolia, Franch., P1. Delavay., 42, t. I 2 (I 889).

China occidentalis. Yunnan; in pratis alpinis, IO-I 2,000 p.s. m.

Habit of Cathcartia villosa but almost glabrous, with rather fewer radical leaves, and purplish flowers. The ripe capsule is not yet known.

3. Cathcartia polygonoides, Prain. Folia glabrescentia radicalia perpauca ovato-oblonga obtusa minopere inciso-crenata; flores parvuli purpurascentes vel albo-coerulescentes saepissime singuli caulem terminantes; stamina I6; capsula (haud matura) ovata in stylum distinctum sensim attenuata; stigma clavatum. Prain, Journ. As. Soc. Beng., lxiv. 2. 326 (1895); Ann. Roy. Bot. Gard. Calcutta, ix. I. 6, t. 8 (I9or).

Himalaya ORIentalis. Chumbi in pratis alpinis, IO-12,000 p.s. m.

Exceedingly like $C$. betonicifolia, of which it might almost be considered a reduced form. It differs from that species in having narrower acute petals, fewer stamens, and hardly any radical leaves.

4. Cathcartia 1yrata, Cumm. \& Prain. Folia glabrescentia radicalia pauca varie hastata integra vel lobata lyrato-pinnatifida; flores parvuli purpurascentes vel coerulei, in cymas racemiformes "paucifloras caulem terminantes dispositi vel singuli caulem terminantes; stamina I6 ; capsula anguste cylindracea in stylum distinctum sensim attenuata; stigma clavatum; semina laevia raphe ecristata. Cumm. \& Prain, Journ. As. Soc. Beng., lxiv. 2. 325 (I 895); Ann. Roy. Bot. Gard. Calcutta, ix. I. 5, t. 7 (I90I).

Himalaya orientalis. Sikkim; in pratis alpinis, II-I4,000 p.s. m.

Differs from Cathcartia villosa in its smaller size, different foliage with fewer radical leaves, smaller blue-purplish flowers with narrower petals erose at the apex, fewer stamens, distinct style, narrow stigma, and uncrested seeds.

\section{SPECIES EXCLUDENDAE.}

Cathcartia Delavayi, Franch., Bull. Soc. Bot. Fr, xxxiii. 390 (I 886). = Meconopsis Delavayi, Franch. ex Prain, Journ. As. Soc. Beng., lxiv. 2. 3 I I (1895). 
Cathcartia integrifolia, Maxim., Bull. Ac. Imp. Petersb., xxiii. 3 IO (I 876$)$.

$=$ Meconopsis integrifolia, Franch., Bull. Soc. Bot. Fr., xxxiii. 389 (I886).

Cathicartia lancifolia, Franch., Bull. Soc. Bot. Fr., xxxiii.39i (I 886). = Meconopsis lancifolia, Franch. ex Prain, Journ. As. Soc. Beng., lxiv. 2. 3 I I (I 895$)$.

\section{EXPLANATION OF PLATES XXIV AND XXV.}

Illustrating Lieut.-Col. Prain's paper on Meconopsis and Cathcartia.

\section{PLATE XXIV.}

Capsules of Papaver and Meconopsis.

Figs. I, 2. Papaver dubium, Linn. (Herb. Gay., 28). $\times 2$.

Figs. 3, 4. Papaver polychaetum, Schott \& Kotschy (Herb. Orient., Stapf.). $\times 2$.

Fig. 5. Papaver stylatum, Boiss. \& Bal. (Siehe, $\left.9^{6}\right) . \quad \times 2$.

Fig. 6. Meconopsis Wallichiana, Hook. (Herb. Ind. Or. H. f. and T.). $\times 2$.

Figs. 7, 8. Meconopsis integrifolia, Franch. (Herb. E. H. Wilson). Ad nat.

Fig. 9. Meconopsis heterophylla, Benth. (det. W. J. Hooker). $\times 2$.

Fig. Io. Meconopsis crassifolia, Benth. (leg. C. F. Baker; det. Greene). $\times 2$.

Fig. I I. Meconopsis torquata, Prain (leg. Walton). $\times 2$.

Fig. I 2. Meconopsis discigera, Prain (Cave, III5 in Herb. Calcutt.). $\times 2$.

\section{PLATE XXV.}

Meconopsis pseudointegrifolia.

Fig. I. Habitus formaeque figura exempli Meconopseos psendointegrrifoliae vivi in horto botanico regio Kewense culti; magnopere reducti.

Fig. 2. Eiusdem folia, alabastra, flos apertus. Ad nat.

Fig. 3. Seta barbellata; magnopere aucta.

Fig. 4. Ovarium. $\times 2$. 


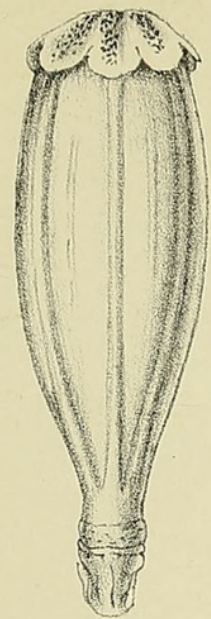

1 .

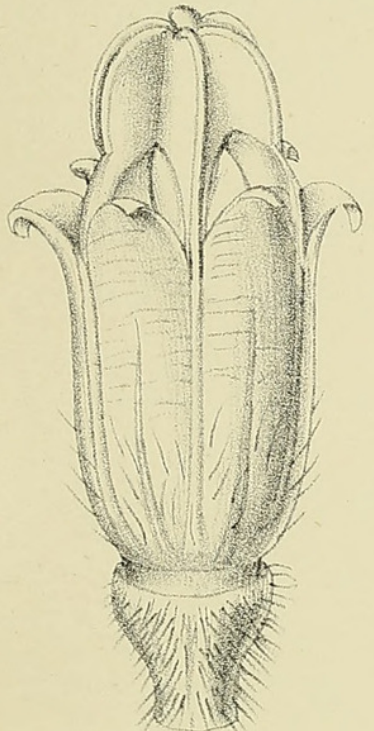

8.

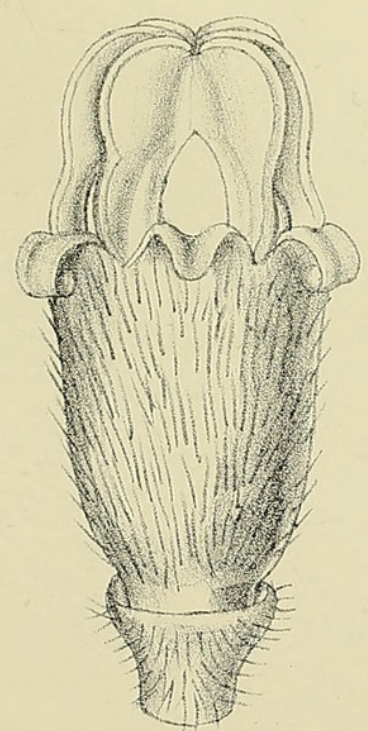

7.

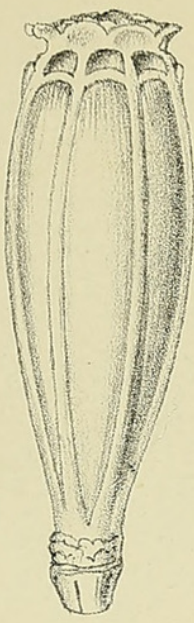

2

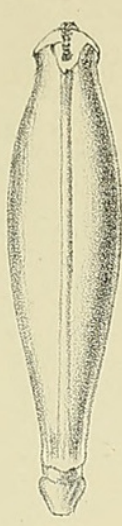

3

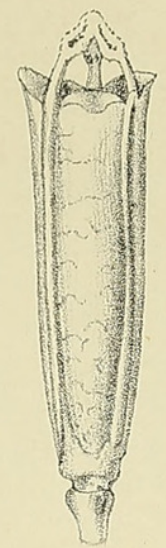

4.

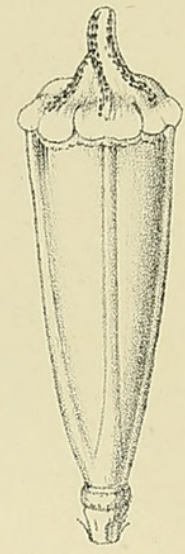

5.
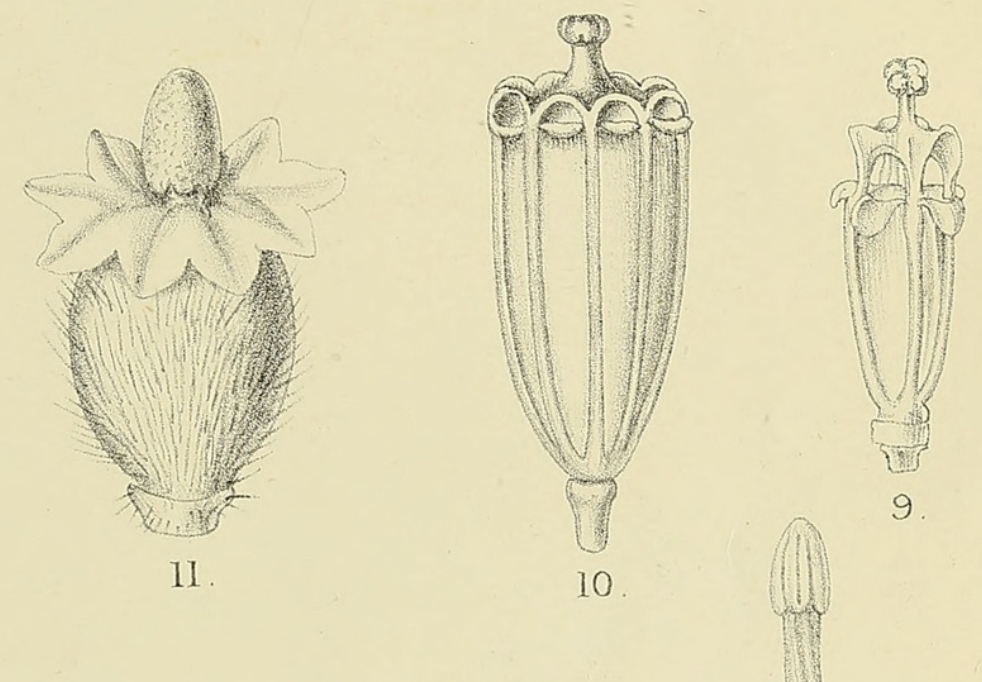

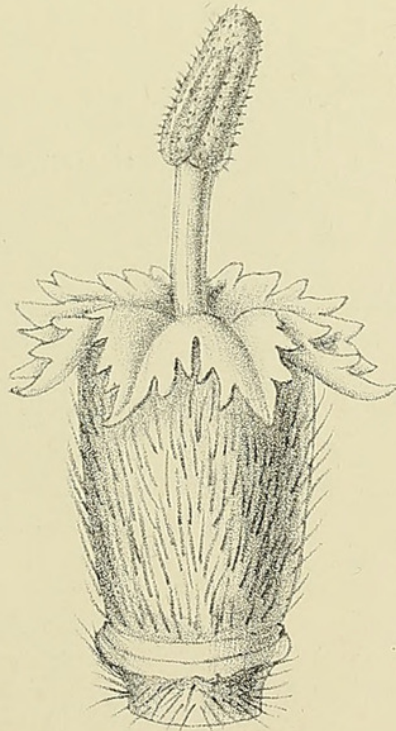

12

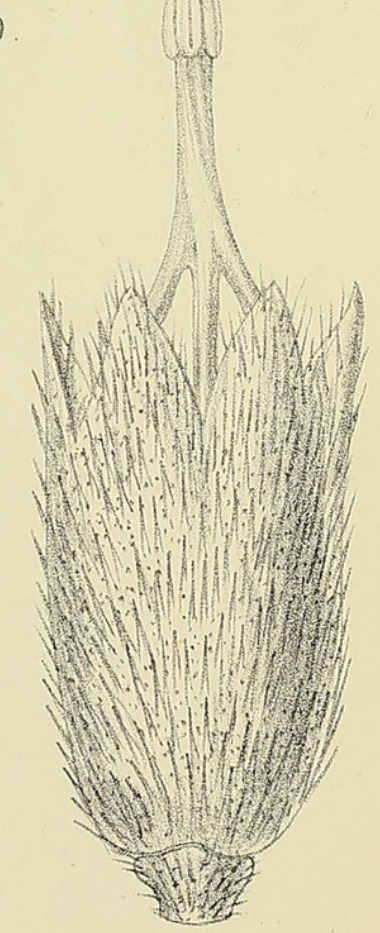

6. 


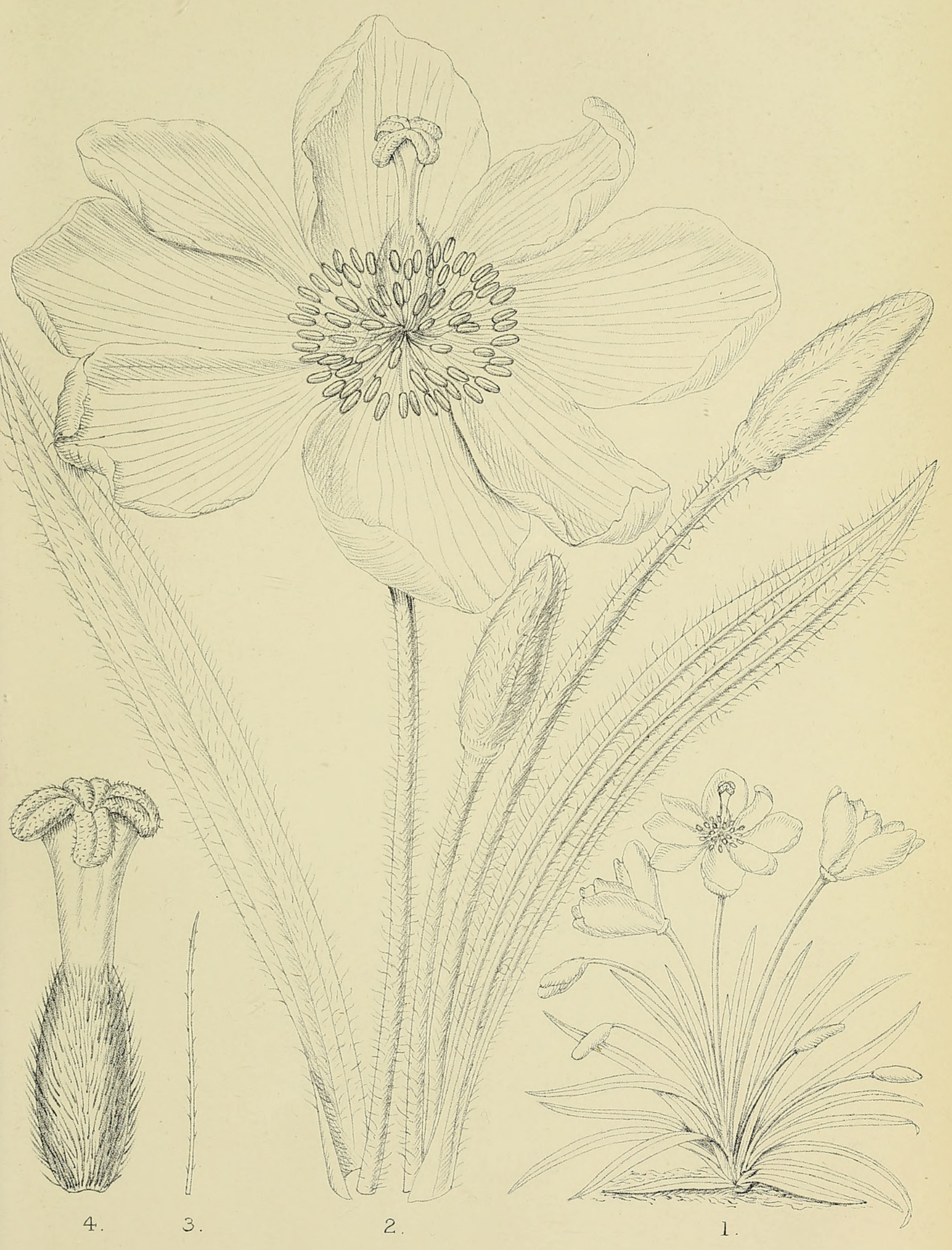




\section{$2 \mathrm{BHL}$ Biodiversity Heritage Library}

Prain, D. 1906. "A review of the genera Meconopsis and Cathcartia." Annals of botany 20, 323-370. https://doi.org/10.1093/oxfordjournals.aob.a089107.

View This Item Online: https://www.biodiversitylibrary.org/item/234848

DOI: https://doi.org/10.1093/oxfordjournals.aob.a089107

Permalink: https://www.biodiversitylibrary.org/partpdf/318847

\section{Holding Institution}

Smithsonian Libraries

\section{Sponsored by}

Biodiversity Heritage Library

\section{Copyright \& Reuse}

Copyright Status: Not in copyright. The BHL knows of no copyright restrictions on this item.

This document was created from content at the Biodiversity Heritage Library, the world's largest open access digital library for biodiversity literature and archives. Visit BHL at https://www.biodiversitylibrary.org. 